\title{
La convivencia según la Escuela Agustiniana Española del siglo XVI
}

(continuación)

\author{
IV. FRAY LUIS DE LEÓN
}

\section{LA SOLEDAD}

a) Las inocentes soledades

Dichoso el que jamás ni ley, ni fuero, ni el alto tribunal, ni las ciudades, ni conoció del mundo el trato fiero; que por las inocentes soledades recoge el pobre cuerpo en vil cabaña y el ánimo enriquece con verdades 274.

Inocentes son las soledades, los campos desiertos, "los sombríos y repuestos valles" 275 , la naturaleza. Los hombres son pecadores. Su trato, fiero, salvaje.

San Juan de la Cruz, perseguido por los carmelitas descalzos, paseaba una mañana por el campo. Ante una encrucijada, le dijo a su acompañante: "vámonos por esto, que no está pisado; que no ha pasado por aquí nadie que

274. P 22, 47-52. Cito por Obras Completas Castellanas de fray Luis de León, Edición del P. Félix GARCÍA, BAC, Madrid 1951, $2^{\text {a }}$. Uso las siguientes abreviaturas: $N=$ De los nombres de Cristo, número del libro, título del nombre y página. $C=$ Exposición del Cantar de los Cantares, capítulo y número. $P C=L a$ perfecta casada, capítulo y página. $J=$ Exposición del libro de Job, capítulo y número. $P$ =Poesías, número de la poesía y número del verso o versos. Opera = Obras latinas, Edición de Salamanca 1895. Otras ediciones las citaré en su lugar. La Revista Agustiniana publicará próximamente, en varias entregas, un trabajo mío sobre La soledad según fray Luis de León, al que seguirá, Deo volente, otro sobre La convivencia según fray Luis de León.La primera entrega ya está publicada en Revista Agustiniana XXXIX (1998) 353-428.

275. N, 1, Pastor, 447. 
haya ofendido a Dios" ${ }^{276}$. Destinado al convento de Sierra Morena, le comenta una monja: “¡dónde se ha de ir vuestra reverencia, padre!”. Y él le contesta: "hija, entre las piedras me hallo mejor que con hombres" 277. Una mañana estuvo arrancando garbanzos. Lo cuenta en una carta: "es lindo manosear estas criaturas mudas, mejor que no ser manoseados de las vivas" 278.

En el apartamiento de las sierras, libre de "la envidia y mentira" ${ }^{279}$, casi "desnudo de este corporal velo" ${ }^{280}$, el espíritu asciende hasta "la más alta esfera" 281 , y allí contempla "la verdad pura sin duelo" 282 . Basta salir de la ciudad al campo, "al campo va mi amor y va a la aldea" 283; contemplar la tierra vestida de hermosura; el deleitoso espectáculo del sol llamando de mañana con sus lanzas de oro a todos los seres a la vida, y la fiesta que estos le preparan 284; el cielo florecido de estrellas que bajan hasta el Tormes, y lo convierten en otro cielo ${ }^{285}$; bañarse en "la luz no usada" 286 , "no corrompida" 287 , para que el alma, rauda saeta, haga blanco en aquellos otros campos celestiales, los campos auténticos, ejemplares ${ }^{288}$.

Solus cum Solo. "Dichoso el humilde estado / del sabio que se retira / de aqueste mundo malvado, / y con pobre mesa y casa, / en el campo deleitoso, / con solo Dios se compasa, / y a solas su vida pasa /ni envidiado ni envidioso" 289 . Hay que huir del mundo y quedarse a solas con Dios 290.

\section{b) La Oda I: Vida retirada}

Una de las poesías peor interpretadas de fray Luis (es un autor complejísimo) es la que en todas las ediciones va en primer lugar. "¡Qué descansada vida / la del que huye el mundanal rüido, / y sigue la escondida / senda por

276. Fray CRISÓGONO DE JESÚS, Vida de san Juan de la Cruz, en Vida y Obras de san Juan de la Cruz, edic. cit., 303..

277. Id., ib., $i b$.

278. Cartas 29, 376.

279. $P, 23,1$.

280. $P, 15,31-32$.

281. $P, 5,17$.

282. $P, 8,5$.

283. $P$, traducción de Tibulo, 1 .

284. Cf. $P C, 6,273-274$.

285. Cf. N, 2, Rey de Dios, 581; f́b., íb., Príncipe de la Paz, 585-587.

286. $P, 5,2$.

287. $P, 15,35$.

288. Cf. $N, 1$, Pastor, $447 ; P, 12,76-80$.

289. $P, 23,3-10$.

290. Cf. José VEGA „Las poesías de fray Luis de León, en francés, en Estudio Agustiniano 22 (1987) 456-460. 
donde han ido / los pocos sabios que en el mundo han sido" 291 . Hasta hay quienes se imaginan a fray Luis plantando lechugas en La Flecha. Los más dicen que anda por aquí el recuerdo del beatus ille horaciano, aquella brutal sátira del logrero Alfio contra los labradores, muy divulgada en el Renacimiento y traducida por fray Luis; pero que aquí no ha dejado huella especial. En la oda de fray Luis estamos muy lejos del beatus ille. Los recuerdos de otros poemas horacianos sí afloran a lo largo de ella.

Lo que en ella se celebra es la vida retirada, tema entonces muy en boga, de clara ascendencia grecolatina. Pero la vida retirada en fray Luis es la soledad en Dios, el camino místico 292, "la escondida senda", soli Deo o Solus cum Solo. "El mundanal ruido" son las pasiones; es el ansia de riquezas, honores y placeres que aqueja al hombre, como se ve por las estrofas siguientes, sin necesidad de acudir a otros textos de fray Luis y de la tradición espiritual en la que él se mueve. Por los votos de pobreza, obediencia y castidad, los religiosos huyen del mundo y se retraen al monasterio, siguen "la escondida senda". Se retraen incluso de sí mismos, y se refugian en Dios. "A vuestro almo reposo / huyo de aqueste mar tempestuoso" 293.

Por amor de Dios, por su gracia, "los yermos desiertos se vistieron de religiosas hayas y cedros, y esos mismos cedros con ella se vistieron de verdor y de fruto, y dieron en sí reposo y dulce y saludable nido a los que volaron a ellos huyendo del mundo. Y no sólo proveyó Dios de nido a aquestos huidos, mas para cada un estado de los demás fieles hizo sus propias guaridas" 294.

Fray Luis hace una exégesis alegórica del salmo 104 (103). A cada uno de los elementos de este mundo visible le corresponde otro en el invisible inaugurado por Cristo. Por ejemplo, a la lluvia le corresponde la gracia; a las hayas y cedros los religiosos, que viven en estado de perfección, más alto que las guaridas de los otros estados, aunque todos tienen su origen en Dios, y, en consecuencia, todos están llamados a la santidad. Se comprende perfectamente que fray Luis hable de las religiosas hayas. "¡Qué maravilla de adjetivo!", comenta el P. Félix García en su Introducción a De los nombres de Cristo ${ }^{295}$. Pero fray Luis no aplica el adjetivo religiosas a las hayas árboles, que sería una imagen casi lorquiana. Las hayas y los cedros, por su altura y por su corteza y hojas oscuras, austeras, ásperas, se convierten en imagen de los reli-

291. $P, 1,1-5$.

292. Cf. Ricardo SENABRE, La "escondida senda" de fray Luis de León, en Tres estudios sobre fray Luis de León, Unversidad de Salamanca, Salamanca 1978, 7-36.

293. $P, 1,24-25$.

294. N, 1, Padre del Siglo Futuro, 506.

295. En fray Luis de LEÓN, Obras completas castellanas, edic. cit., pp. 367-368. 
giosos, de los que huyen del mundo, y, muy concretamente, de los que huyen al desierto, a "los sombríos y repuestos valles" ${ }^{296}$, al "secreto seguro, deleitoso" ${ }^{297}$, que son, como veremos, los que más alto vuelan. Las religiosas hayas son los Padres del Yermo y sus imitadores, los que siguen "la escondida senda". No tan "maravilloso" el adjetivo.

"Vivir quiero conmigo, / gozar quiero del bien que debo al cielo, / a solas, sin testigo, / libre de amor, de celo, / de odio, de esperanzas, de recelo" ${ }^{298}$. Es la tranquilidad del sabio estoico ${ }^{299}$; pero del sabio estoico que es cristiano y cristiano con un modelo de espiritualidad, el monástico. Es la tranquilidad del religioso que vive retraído en su monasterio o en los apartados montes, en soledad con Dios. "Vivir consigo" fue lema de los sabios antiguos; lo fue de san Gregorio Magno y de muchos otros. Hay muchas maneras de vivir consigo. En soledad con Dios, dicen los monjes; en una soledad muy ocupada. Solo, para "gozar del bien que debo al cielo", para gozar de la gracia de Dios, de su amor, de sus beneficios.

Los justos, los perfectos, "los pocos sabios que en el mundo han sido" 300 , los que han sido convidados por el Esposo a su bodega, y han bebido de su adobado vino y de su mosto de granadas, ya no se recatan del mundo, y "en público y en secreto gozan de la suavidad de estos amores", y la expresan sin temor al qué dirán. Sin embargo, "estos mismos sienten un particular gusto y una libertad desembarazada cuando se ven a solas con Dios, sin compañeros ni testigos [a solas, sin testigo]. Y por esto dice que te halle fuera; lo cual en todo amor es natural los que bien se aman amar la soledad y aborrecer cualquier estorbo de compañía y conversación. Porque el que ama y tiene presente lo que ama tiene llena su voluntad con la posesión de todo lo que desea; y así no le queda deseo ni voluntad ni lugar para querer ni pensar otra cosa. De donde nace que todo lo que le divierte [aparta] algo de aquel su amor y gozo, poniéndosele delante, le es enojoso y aborrecible como la muerte" ${ }^{301 .}$

En la enamoración, la atención se angosta, se concentra sobre la persona amada, y todo lo demás desaparece. La conversación con otra persona resulta enojosa, aborrecible. Se nos iluminan los textos que hemos leído. Quienes en ellos hablan son almas en proceso de enamoración. No pueden dar cabida

296. $N, 1$, Pastor, 447.

297. $P, 1,22$.

298. $P, 1,36-40$.

299 Cf. Fray Luis de LEÓN, Poesía, edición de Juan Francisco Alcina (Letras

Hispánicas 184), Ediciones Cátedra, Madrid 1989, $3^{\text {a }}, 71$

300. $P, 1,5$.

301. $C, 8,2$. . f. $C, 8,8$. 
en su corazón a ninguna criatura. Y Dios es un amante celoso, que pide cuentas del menor desvío.

Pero la enamoración no es un estado de por vida. Superada, el individuo puede volver a ocuparse de otras personas y atender a más asuntos. Los espirituales, en cambio, se quedan en una dulce enamoración de por vida, "en soledad de amor", "que ya sólo en amar es mi ejercicio" (san Juan de la Cruz). Y así se están, "amado con amada, / amada en el amado transformada" (san Juan de la Cruz). Solus cum solo, como si únicamente existieran ellos dos solos en el mundo, "como si otra persona en él no viviese" 302. De ahí el aire de sonámbulos que tienen todos ellos. Toda compañía les resulta enojosa, aborrecible; toda conversación, desabrida. Los tratadistas llaman a este estado "amor esponsal"; "enamoración a lo divino" les cuadra mejor.

"Así que si en toda amistad pasa esto así, pero señaladamente más que en otra ninguna se ve en la que se enciende entre Dios y el alma del justo [...]. Los que por gran don suyo, enamorados de este bien [gozar quiero del bien que debo al cielo], comienzan a tener gusto de él, gustan de él incomparablemente más que de otro; o, por mejor decir, no les queda cosa de voluntad ni entendimiento ni gusto libre para gustar de otro. Cuando le tienen ausente, él solo es su deseo; cuando, por secretos favores, se les da presente, arden en vivo fuego; $y$, ricos con la posesión de un bien tamaño, juzgan por desventurada y mala suerte todo lo que fuera de él se les ofrece.

$\mathrm{Y}$ en tanto grado aman la soledad y se molestan de todo lo que les ocupa cualquier parte de su voluntad, por pequeña que sea, que si en estado tan bienaventurado como es el suyo se compadece haber pena o falta, no sienten otra si no es la de su entendimiento y voluntad, que por su natural flaqueza y limitación quedan atrás en el amor que se debe a bien tan excelente. De aquí es que los tales, por la mayor parte, se apartan de los negocios de esta vida, huyen el trato y conversación de los hombres, destiérranse de las ciudades y aman los desiertos y montes, viviendo entre los árboles, solos al parecer y olvidados [libre de amor, de celo, de odio, de esperanzas, de recelo]; pero a la verdad alegres y contentos, y tanto más cuanto en vivir así están más seguros de que ninguna cosa les podrá cortar el hilo de su bienaventurado pensamiento y deseo que de contino en el corazón les tira y les hace decir con la esposa: ¿quién te me dará, hermano mío, criado a los pechos de mi madre, que te halle fuera? [...Quiere] allegarle consigo y abrazarle con un nuevo y entrañable amor; meterle en su casa y en lo más secreto de su amor hasta transformarse toda en él y hacerse una misma cosa con él" ${ }^{303}$.

302. San JUAN DE LA CRUZ, Cuatro avisos a un religioso..., 2.

303. $C, 8,2$. 
"Vivir quiero conmigo", solitario, célibe, amando a Dios con corazón indiviso, a diferencia de los casados, cuya vida "está dividida por la diversidad de preocupaciones y negocios a los que está sometida", como escribió san Pablo $(1$ Cor 7,33$)$ 304. "Vivir quiero conmigo": toda la tradición monástica está condensada en este verso. Monje es el que vive consigo, fugitivo de este mundo, fugitivo de sí mismo; el solitario (y a esto alude su etimología), célibe, consagrado por la castidad a Dios, a Dios solo; recobrando por ella la unidad perdida por el pecado, recuperando el paraíso.

Comprendemos ahora que el huerto de que habla fray Luis a continuación no es La Flecha ${ }^{305}$. Esta es sólo, a lo sumo, el apoyo que necesita la imagen. El huerto es el alma del justo, el alma de fray Luis en gracia de Dios, arrebatada por la caridad. Huerto plantado "del monte en la ladera", es decir, en la humanidad de Jesucristo. Huerto primaveral y florido, al que baja el Esposo a recrearse. Huerto que "ya muestra en esperanza el fruto cierto" de la salvación. De "la cumbre airosa" del monte, de la divinidad de Jesucristo, se apresura hasta el huerto "una fontana pura", la fuente de la gracia, "codiciosa por ver y acrecentar su hermosura". Y lo enjoya y florea de virtudes, convirtiéndolo en un vergel oreado por el Espíritu ${ }^{306}$. "El aire el huerto orea / y ofrece mil olores al sentido". Son "las emisiones de bálsamo divino" (\$an Juan de la Cruz), las fragancias del Esposo del Cantar (cf. C 1,2), que, como la música de Salinas, "despiertan los sentidos, / quedando a lo demás adormecidos" 307 . Al "mundanal ruido" de la primera estrofa se opone ahora un "manso ruido" garcilasiano, "el silbo de los aires amoroso" (san Juan de la Cruz), la "brisa tenue" (sibilus aurae tenuis) en la que Dios habló al profeta Elías $(1 \operatorname{Re} 19,12)$.

En olvido, en profundo olvido, han caído "el oro y el cetro" 308 y "la belleza caduca, engañadora" ${ }^{309}$ riquezas, honores y placeres, que traen a mal traer a los hombres, como se dice en las estrofas siguientes.

Y mientras los otros se abrasan "con sed insaciable / del no durable mando", él, el yo lírico que habla en la oda, reposando a la sombra de su huer-

304. Cf. Exposición del Salmo 67, 7, en José María BECERRA HIRALDO, Obra mística de fray Luis de León, Universidad de Granada 1986, 305.

305. $P, 1,41-60$.

306. José VEGA, art. cit., 468-471. Para el sentido metafórico de monte, cf. $N, 1$, Monte, 460-476; José VEGA, La metáfora en "De los nombres de Cristo" de fray Luis de León, Editorial Estudio Agustiniano, Valladolid 1987, 45-47.

307. $P, 5,43,45$.

308. $P, 1,60$.

309. $P, 5,15$. 
to, escucha con "atento oído" el "son dulce, acordado / del plectro sabiamente meneado" 310 , el "son sagrado / con que este eterno templo es sustentado" 311 , el sagrado concierto de "aquesta inmensa cítara" 312; la música "no perecedera" 113 , que llega de la casa del Padre 314; música "que es la fuente y la primera" de todas 315 . Y su alma, compuesta de "números concordes" con esta música divina, le "envía / consonante respuesta" 316 "y entrambas a porfía / se mezcla una dulcísima armonía" ${ }^{117}$. ¡Extraordinario, divino fray Luis! Aire de cumbre es el que en él respiramos.

\section{c) El hombre, negación de Dios; huida del mundo}

Pero ahí están los hombres, los del "trato fiero" 318, "siendo su trato de ellos tan pesado y tan impertinente como sabemos" 319; "aqueste mundo malvado" 320 , "el aprieto / del miserable bando, / que las saladas olas va cortando" 321; selva donde triunfan "la fiereza del tigre" y "el basilisco emponzoñado" 322

En nuestra naturaleza, dice fray Luis, buen conocedor de san Agustín, hay "alguna enfermedad y daño encubierto"; no está "pura y como salió de la mano del que la hizo, sino dañada y corrompida o por desastre o por voluntad [...]; tan inclinada al pecado, que por la mayor parte, no alcanzando su fin, viniese a extrema miseria” "323. “Cómo Dios en un cuerpo tan indomable y de tan malos siniestros y en tanta tempestad de olas de viciosos deseos como en nosotros sentimos [...habría podido poner] una razón tan flaca y tan desnuda de toda buena doctrina, como es la nuestra cuando nacemos? [La razón está colocada] en medio de sus enemigos, sola contra tantos y desarmada contra

310. $P, 1,78-85$.

311. $P, 5,24-25$

312. $\mathrm{Ib}, \mathrm{2} 2$.

313. Ib., 19.

314. "Siguiendo una cierta dulzura, oyendo una cierta melodía interior, abstrayéndose de todo ruido de carne y sangre, llegó hasta la casa de Dios [...]. En la casa de Dios, hay fiesta permanente [...]. De aquella eterna y perdurable fiesta suena no sé qué dulce melodía en los oídos del corazón cuando enmudece el mundo. La música de aquella fiesta cautiva el oído" (san AGUSTÍN, Comentarios a los salmos, 41, 9).

315. $P, 5,20$.

316. $f b, 27-28$.

317. $\mathrm{Ib}, 29-30$.

318. $P, 22,49$.

319. N, 3, Cordero, 773.

320. $P, 23,5$.

321. $P, 15,38-40$.

322. $P, 4,26-28$.

323. N, 2, Dedicatoria, 513. 
tan poderosos y fieros. [Ya antes de despertar la razón] viven en nosotros y se encienden los deseos bestiales de la vida sensible [...]. En abriendo la razón los ojos, están como a la puerta y como aguardando para engañarla el vulgo ciego y las compañías malas y el estilo de la vida llena de errores perversos, y el deleite y la ambición y el oro y las riquezas que resplandecen [...]. Todo junto, y como conjurado y hecho a una para hacer mal" 324 .

El hombre es la negación de Dios. Tenemos que desasirnos de ellos, evitar su compañía, si queremos encontrar a Dios. Huir, huir de los hombres, de su conversación y trato, y refugiarse en Dios, solus cum Solo, es el único camino, "la escondida senda" para encontrar la paz y la salvación. "¡Oh ya seguro puerto / de mi tan luengo error! ¡Oh deseado / para reparo cierto / del grave mal pasado,/ reposo dulce, alegre, descansado!" 325 .

\section{d) Fuera del claustro no hay salvación}

Todos están llamados a la santidad. Cada uno se santifica en su estado. Es esta una idea tradicional, muy manoseada en los siglos XV-XVII ${ }^{326 .}$

"Lo propio y particular que [Dios] pide a cada uno es que responda a las obligaciones de su oficio, cumpliendo con la suerte que le ha cabido, y que, si en esto falta, aunque en otras cosas se adelante y señale, le ofende [...]. Los hombres que se descuidan de su oficio, aunque en otras virtudes sean cuidadosos, no contentan a Dios [...]. No quiere Dios en su casa al que no hace el oficio en que le pone. Dice Cristo en el Evangelio que cada uno tome su cruz (Mt 16,24); no dice que tome la ajena, sino que manda que cada uno se cargue de la suya propia. No quiere que la religiosa se olvide de lo que debe al ser religiosa y se cargue de los cuidados de la casada; ni le place que la casada se olvide del oficio de su casa y se torne monja. El casado agrada a Dios en ser buen casado, y en ser buen religioso el fraile, y el mercader en hacer debidamente su oficio; y aun el soldado sirve a Dios en mostrar en los tiempos debidos su esfuerzo y en contentarse con el sueldo, como dice san Juan (Lc 3, 14)" ${ }^{227}$.

Todo esto suena muy bien. Cada uno se santifica en su oficio; pero es el teólogo quien señala a cada uno en qué consiste éste (los oficios, los estados de la Iglesia y los estamentos sociales son de orden divino, y es Dios quien coloca a cada uno en el lugar debido: es, pues, competencia del teólogo decir

324. $I b, 514$.

325. $P, 15,1-5$

326. Cf. José VEGA, La vocación agustiniana. El proyecto filosófico-monástico-sacerdotal de san Agustín, edic. cit., 193-201.

327. PC, Introducción, 237-238. 
a cada uno lo que tiene que hacer), y el modelo de santidad que les propone a todos es el monástico. No había otro. Es el modelo de la caridad o amor de caridad, que exige desasirse de toda criatura, de todo afecto humano, y entregarse en cuerpo y alma a Dios, solo a él. Oscuro se les presenta el horizonte a los seglares que aspiren a la santidad.

Dos clases de cosas retardan y dificultan la santidad, dice fray Luis. En primer lugar, la administración de negocios terrenos (el cuidado de la familia y el desempeño de oficios públicos u otros asuntos), a no ser que se anteponga el amor de Dios a todos ellos. En segundo lugar, la concupiscencia inserta en nuestra naturaleza. La caridad perfecta tiene sedada la concupiscencia, sometida a la ley divina, sin que apenas se atreva a rebullirse, y vacía al alma de todo cuidado público y privado. Primero hay que renunciar a las preocupaciones del siglo; luego, arrancar los malos deseos ${ }^{328}$.

\section{e) Desencarnación}

Hay, pues, que despojarse, vaciarse, desnudarse de todo afecto humano, alienarse o enajenarse de las criaturas, olvidarse de ellas, también de uno mismo; negar al hombre, deshumanizarse, y ponerse bajo el dominio de Dios, consagrarse a él. No hay valores humanos; son sólo apariencia, "similitud de virtudes", como dice Orozco con san Agustín. Hay que desencarnarse, dice fray Luis, liberarse de todo lo significado por la carne, de todo lo humano. Es lo que, al menos en teoría, hacen los religiosos mediante los votos y observancias: romper con las riquezas, con la propia familia, con el propio cuerpo y la propia voluntad; quemarlo todo en holocausto.

"Por amor de este Amado y por agradarle, ¿qué prueba no han hecho de sí infinitas personas? Han dejado sus naturales; hanse despojado de sus haciendas, hanse desterrado de todos los hombres, hanse desencarnado de todo lo que se parece y se ve; de sí mismos mismos ${ }^{329}$, de todo su querer y entender hacen cada día renunciación perfectísima. Y si es posible enajenarse un hombre de sí y dividirse de sí misma nuestra alma, y en la manera que el espíritu de Dios lo puede hacer y nuestro saber no lo entiende, se enajenan y se dividen amándole. Por él les ha sido la pobreza riqueza y paraíso el

328. Cf. In Cant.cant. trip. explan., en Fray Luis de LEÓN, Cantar de los Cantares, texto bilingüe, traducción, introducción y notas de José María BECERRA HIRALDO, Ediciones Escurialenses, Real Monaterio de El Escorial 1992, 5, 2, 273-280.

329. Restituyo al texto el segundo mismos, suprimido en la edic. de Félix GARCÍA por creerlo errata. De sí mismos mismos quiere decir de sí mismísimos. La reduplicación equivale a un superlativo. Hay que desencarnarse de raíz, raer lo humano sin dejar rastro alguno. 
desierto y los tormentos deleite y las persecuciones descanso; y para que viva en ellos su amor, escogen el morir ellos a todas las cosas y llegan a desfigurarse de sí, hechos como un sujeto puro sin figura ni forma, para que el amor de Cristo sea en ellos la forma, la vida, el ser, el parecer, el obrar, y finalmente para que no se parezca en ellos más de su Amado. Que es, sin duda, el que sólo es Amado por excelencia entre todo" 330. Jesús "extiende su mano saludable y la pone en nuestro cuerpo malsano y templa sus infernales ardores, y lo mitiga y desencarna de sí, y casi lo transforma en espíritu" 331. "Sólo sienten el mal de la muerte los que pusieron toda su afición, sus pensamientos, su felicidad en el cuerpo y en los sentidos corporales, que se extinguen con la muerte. Pero a los buenos y a los alejados del contacto del cuerpo y a los vacíos de afecto y a los que aspiran siempre al cielo y los regalos celestiales, ¿qué les arrebatará la muerte cuando venga?" ${ }^{332}$.

\section{f) A solas con Dios solo}

Amor a la soledad, en la que habla Dios, por una parte; por otra, olvido y menosprecio de lo humano. Con estos supuestos, tan arraigados en las conciencias, no podemos esperar que fray Luis, que en otros aspectos supo avanzar más allá de las posiciones recibidas, tuviera ojos para ver que el hombre es convivencia, no menos que soledad, y que sólo en la convivencia aparece como tal; que decir hombre es decir comunidad, relación con los otros, reciprocidad.

Hay, pues, que refugiarse en la soledad. Pero no en una soledad desocupada, que es muy peligrosa. "La soledad no es buena; la división y apartamiento es negocio peligroso y ocasionado" 333 . Refugiarse en la soledad de un monasterio, enamorarse de Dios sin reservarse nada; ejercitarse en el despojamiento de todo para que sólo Dios ocupe el alma; huir, una vez probados en la comunidad, a los montes y desiertos, lejos de toda compañía humana. "Sólo Dios basta", decían los espirituales con santa Teresa de Jesus. Sólo en la soledad con Dios se perfecciona el hombre, decían también. Pero hoy sabemos que el alejarse de los demás se paga con el empobrecimiento de uno mismo. El hombre; solo, se deshumaniza; y una comunidad, aislada, también. Deshumanizarse, sin embargo, era lo que ellos se proponían, vaciarse de lo humano, para dejar lugar a Dios.

330. $N, 3$, Amado, 733 .

331. $N, 3$, Jesús, 764.

332. Oración fúnebre a Domingo de Soto, en José María BECERRA HIRALDO, Obra

mistica de fray Luis de León, Universidad de Granada 1986, 62-63.

333. N 3, Hijo de Dios, 671. 


\section{LA CONVIVENCIA}

\section{a) Relaciones de los religiosos}

Religiosos así sólo se aman con amor de caridad. "Con amor espiritual, no carnal", como manda san Agustín ${ }^{334}$; viven "en unanimidad y concordia" 335; tienen "un alma sola y un solo corazón en Dios" 336. Dios es el alma de cada uno y de todos. ¿Se relacionarán tales religiosos entre sî? ¿Cómo podrían relacionarse si están desencarnados "de sí mismos mismos", vacíos de todo afecto humano? Sè relacionarán en Dios y por Dios en los tiempos y lugares señalados, y entonces hablarán de Dios. Su relación será espiritual, puramente espiritual, como hemos visto en santo Tomás de Villanueva y en el beato Orozco.

\section{b) El superior y los celadores}

Oficio es del superior velar para que así sea. La Forma de vivir de los frailes agustinos descalzos 337 establece dos celadores que ayuden al superior en esta tarea. Dos mastines que ayuden al pastor del monasterio a tener bien recogido el rebaño. Uno de ellos oculto (nadie fuera del superior sabía quién era), que le daba cuenta de todo lo que advertía contra las leyes; y otro manifiesto, conocido de todos, nombrado por turno, encargado de corregir en público a los que faltaban a la disciplina ${ }^{338}$. El cargo era ya habitual en las comunidades religiosas de la época (carmelitas, jesuitas, mercedarios, agustinos...) ${ }^{339}$, y venía de antiguo. Gran hallazgo, sin duda, para reprimir aún más la escasa convivencia permitida.

\section{c) Vida eremítica}

También fray Luis creía con toda la venerable tradición que la vida eremítica es la forma superior de vida religiosa. Varios de los textos ya citados se

334. Regla, $6,43$.

335. Ib., 1,9 .

336. $f b ., 1,3$.

337. Se trata de un documento oficial del Definitorio de la Provincia Agustiniana de Castilla, del que fray Luis era miembro. El texto, cualquiera que haya sido la intervención de los otros definidores, es, evidentemente, de fray Luis. Se publicó en 1590. 41-42.

338. Cf. Forma de vivir, 10,1-3, edic. y vocabulario de Pablo Panedas, Mayéutica 15 (1989)

339. Véase, por ejemplo, santa TERESA DE JESÚS, Constituciones, 6, 13 y 9, 6; Jesús Díez, La comunidad en la FORMA DE VIVIR, en Mayéutica 15 (1989) 204-210. Se los llamaba celadores, síndicos, proclamadores, cercadores... 
refieren precisamente a los ermitaños. Hay muchos otros que no voy a citar 340 . Una sola muestra: "nada es tan grato a Dios como que la esposa salga al campo, abandonada casa y ciudad, para verle y gozarle. Lo primero que Dios suele pedir a los suyos es que se sustraigan a las preocupaciones terrenas y se entreguen a un cierto descanso y libertad para vacar a él solo [...]. En los comienzos de la vida espiritual, mientras el alma es ruda, inexperta y fácil a las caídas, es más conveniente vivir con hombres del mismo voto y propósito que llevar una vida solitaria. Pues la vida solitaria y auténticamente monástica es solamente apta para quienes tienen ya sus deseos suficientemente dominados y reprimidos. [Los principiantes deben ejercitarse en compañía de los buenos, dejarse regir por hombres religiosos que les enseñen el camino.] Hecho esto, huyan a los secretos seguros y a las soledades dichosas. A ellas son invitados los aprovechados y perfectos. Pero ahora, mientras son principiantes, se les manda vivir en las cabañas de los pastores y obedecer a otros [...]. Ahora son probados por Dios, no en si, cerreros e indómitos, viven a la manera de las fieras, sino en si quieren someter sus cuellos al yugo, aguantar el freno en la boca, uncirse al carro, ser aguijados con el látigo y ser trajinados" ${ }^{341}$.

He traducido secreta tuto et beatas illas solitudines petant por huyan a los secretos seguros y a las soledades dichosas. Coincide con el secreto seguro, deleitoso, al que fray Luis se dirige huyendo de este mundo en la Oda 1 . Son "los sombríos y repuestos valles" 342 , o imagen de los "deleitosos senos, I repuestos valles de mil bienes llenos" del cielo ${ }^{343}$; el "lugar secreto y deleitoso" ${ }^{344}$, como traduce "al bel seggio riposto, ombroso e fosco" de Petrarca ${ }^{345}$. Son los montes apartados, los valles solitarios, los desiertos a los que huyen los que se alejan de los hombres, como hemos leído en varios textos. Es el secretum iter horaciano ${ }^{346}$, "la escondida senda" de fray Luis, que, después de todo lo que llevamos dicho, espero que entregue al lector su significado profundamente monástico y místico, no sólo estoico ni religioso en general.

A los religiosos, dice fray Luis, hay que trajinarlos, faenarlos, traerlos y llevarlos (circumagi), ejercitarlos en la obediencia, aguijarlos con el látigo

340. Véase, por ejemple, Job 39,8-11.

341. In Cant. cant. trip. explan.,1. 2, en Cantar de los Cantares, edic. cit. de BECERRA HIRALDO, 1, 2, 57-58. La traducción es mía.

342. N, 1, Pastor, 447.

343. $P, 12,79-80$.

344. P, 25, Imitación de Petrarca, 29.

345. Francesco PETRARCA, Cancionero, edición bilingüe de Jacobo CORTINES, Ediciones Cátedra, Madrid 1989, t. II, CCCXXIII, v. 40, p. 914.

346. Epodos, I, 18, 101-103. 
(habenis torqueri). Aquí están las disciplinas que los superiores daban, a veces, a los súbditos, de que nos ha hablado el beato Orozco. Volveré sobre el tema al estudiar a Malón de Chaide ${ }^{347}$.

\section{d) Los agustinos}

Como sus contemporáneos, fray Luis creía que san Agustín había sido ermitaño y fundador de ermitaños, de la Orden de Hermanos Ermitaños de San Agustín, a la que él pertenecía. Y esto marcó su espíritu. En el Discurso del famoso Capítulo de Dueñas (1557), se lee: “¡Ojalá tuviéramos aquellos bosques, ojalá aquellas ocultas y antiguas casas y los que nos llamamos fuésemos verdaderamente ermitaños!" 348 .

\section{FRAY PEDRO MALÓN DE CHAIDE}

Los textos directamente relacionados con la convivencia son escasos en La conversión de la Magdalena; pero el modelo mental que subyace bajo ellos es el mismo que venimos estudiando. Conviene sacarlo a flote, tal como él lo expone, porque cobraremos algunas piezas importantes que hasta ahora no nos han salido. Así comprenderemos mejor los principios en que sustentaban su alejamiento de los hombres, su amor por la soledad y su rechazo de la convivencia.

347. Sobre diversos aspectos de la vida religiosa en fray Luis, cf. Mayéutica 15 (1989), todo el número, dedicado a la Forma de vivir. En él puede leerse a Jesús DÍEZ, La comunidad en la FORMA DE VIVIR, 177-249. En las recreaciones, según la Forma de vivir, "no ha de haber juegos, ni aun de ajedrez ni de bolos..." $(9,29)$, coincidiendo con el espíritu de Orozco, de santa Teresa y demás contemporáneos. Para la vida eremítica puede leerse a Pablo PANEDAS, El carisma en el sello agustino recoleto, en Recollectio 13 (1990) 5-43; a José Luis BENGOA, Fray Luis de León y la Orden de Agustinos Recoletos, en Recollectio 11 (1988) 6869; id., Espiritualidad de la Orden de Agustinos Recoletos, en Recollectio 11 (1988) 523-526. Para la relación de fray Luis con la recolección agustiniana, cf. Carlos ALONSO, Fray Luis de León en el proceso de reforma de la vida religiosa agustiniana, en Teófilo VIÑAS ROMÁN (Coord.), Fray Luis de León. IV Centenario (1591-1991). Actas, Ediciones Escurialenses, Madrid 1992, 409-424.

348. Cito la traducción de BECERRA HIRALDO en Obra mística de fray Luis de León, edic. cit., 35. 


\section{DEL PECADO A DIOS: HUIDA DEL MUNDO Y DESENCARNACIÓN}

Si pecar es alejarse de Dios y entregarse a las criaturas, convertirse será alejarse de las criaturas y volver a Dios. O Dios o las criaturas. "Cuando uno ha errado el camino y va perdido, el más cierto remedio es volver a desandar lo andado [...]. Así el pecador, que se ve perdido, y que ha caminado mucha tierra y dado muchísimos pasos hacia el infierno, el remedio que le queda es desandar lo andado y volver atrás, como Teseo, que ató el hilo a la puerta del laberinto de Creta, por atinar a salir otra vez" ${ }^{449}$. El pecador, "apartado de Dios, con el auxilio divino, saliendo de sus vicios, hace penitencia y se vuelve a Dios" 350 .

El hombre, de suyo, es polvo, pecado y miseria, nada. El pecador, soberbio, se cree algo. Es preciso que se humille. "Si subisteis por soberbia [...], de aquí adelante bajéis otro tanto por humildad, hasta dar con vos en tierra y conocer que sois polvo y que valéis nada y menos que nada, y entonces sanaréis de la ceguera de vuestro entendimiento" ${ }^{351}$. Dios creó todas las cosas para sí, para su gloria y servicio. Esta es la idea central en el paradigma religioso de la época. Está por hacer la historia de la idea de Dios que han tenido los hombres a lo largo de los siglos, pero es evidente que en el cristianismo han confluido muchas y muy diversas tradiciones, que, a veces, lo han apartado bastante de la que se nos da en los Evangelios. Las criaturas son propiedad de Dios, dueño de todo. El pecador se las apropia, "quita a Dios lo que es suyo" 352. Siendo "heredad de su Dios y dejándose disfrutar del demonio por el pecado", no cumple con devolver a Dios lo que le quitó, sino que tiene que satisfacerle por "el tiempo que ha dejado de servirle y le ha defraudado de todo aquello" 353 .

El hombre, en realidad, aunque otra cosa dijeran, no es libre. Dios es Señor absoluto de su alma y de su cuerpo, de su hacienda y de todas las criaturas. Desde la eternidad, predestinó a unos a la salvación y a otros a la condenación. El hombre puede sustraerse a sus leyes; huir de él como el esclavo de la casa de su señor, pero no de su dominio y señorío. Dondequiera que vaya, es del Señor, que es todopoderoso, y hace cumplir su ley inexorable-

349. III, $3^{\text {a }}$, 45, 56-57. Cito por Malón de CHAIDE, La conversión de la Magdalena, prólogo y notas del P. Félix GARCÍA (Clásicos Castellanos 104, 105 y 130), Espasa-Caalpe, Madrid 1959,1957 y 1958,3 vols. Los vols. $1^{\circ}$ y $2^{\circ}$ son de la $3^{a}$ edic.; el vol. $3^{\circ}$, de la $2^{a}$. Cito volumen, parte, capítulo, y página o páginas, por este orden.

350. III, $3^{\text {a }}$, prólogo del tercer estado de la Magdalena, 77.

351. III, $3^{\mathrm{a}}, 45,57$.

352. $\mathrm{Ib}$, ib., 62 .

353. Ib., ib., 63. 
mente. Cada paso que dé en su huida será acercarse, cada vez más, al infierno. De Dios son "todas sus obras [del hombre], todas sus palabras y todos sus deseos y pensamientos; y por esto dice el Señor que de todo esto han de dar cuenta" 354. La conclusión se impone: hay que pensar en Dios, sólo en él; desearle sólo a él, amarle sólo a él, hablar sólo de él. Lo contrario es quitarle a Dios lo que es suyo (esta idea tradicional de Dios hace agua por todas partes).

Para llegar a Dios hay que dejar atrás todas las criaturas, despojarse de todo afecto a ellas. "Creía yo, mujer pecadora, que en los tratos de la ciudad, en la trulla y herrería del mundo, allí estaba, y que por sola mi diligencia y cuidado toparía con él. Y no sabía que el bien de mi alma estaba fuera de todas las criaturas, y sobre todas ellas, y que todo es menester dejarlo atrás para hallarle; que se han de pasar los elementos [la tierra, el aire, el agua y el fuego], las plantas, los brutos, los hombres, cielos, ángeles, serafines y todo lo creado para hallar al mi Esposo celestial [...]. Olvidada de todo lo que atrás queda, pasando las cosas mundanas, y a las guardas y a los santos ángeles, comencé a correr con mayor ansia y priesa [...]; y en despreciando y no haciendo caudal de los ángeles, y en levantando los deseos sobre los serafines, luego de allí a un poco, porque todo lo sensible es menester sobrepujar, hallé al que ama mi alma" 355 .

Para que el hombre pueda llegar a Dios tiene que huir incluso de sí mismo; desencarnarse mortificando o matando su propio cuerpo. Alma, "tanto sois más noble, cuanto más contraria os mostráis de lo que es cuerpo. Bueno os es estar con vuestro Padre, y malo estar con el cuerpo", dice Orígenes en un sermón que traduce Malón de Chaide como conclusión de su libro 356. La "tierra maldita del cuerpo es seca y estéril" 357. Para hacerla "fértil y de mucho fruto, el remedio mejor es regarla a menudo, y por eso lloraban tanto los santos. [Cada lágrima de penitencia es un grano de trigo que se siembra y] por cada grano nos han de dar ciento de gloria" 358. "Desnúdese del cuerpo y suba sola el alma a la región del sobrecelestial resplandor, y pasando todo lo sensible a lo inteligible, entre con Moisén [así se decía] en la niebla y caligine divina, que huelgo de decirlo por este término latino, adonde vio Moisén a Dios [...]. Entre V. M. en aquella niebla, y allí absorta y embelesada, deslumbrada del resplandor inmenso, ciega a todo lo de acá abajo, descu-

354. fb., $i b$.

355. II, $3^{\mathrm{a}}, 39,250-252$.

356. III, 215.

357. II, $3^{\mathrm{a}}, 39,228$.

358. $l b, i b ., 229$. 
brirá los admirables efectos y grandezas del gran Dios de amor, adonde, ardiendo con aquellas mentes angélicas, hecha divina mariposa, apurada en la llama y rayo de la luz soberana, y con el fuego del Amante eterno, consumirá todo lo terreno que acá en esta mortal región y escuro suelo se nos pega" 359 .

\section{DOS INCENTIVOS DEL PECADO: LOS LIBROS LASCIVOS Y LAS MUJERES}

Cualquier asomo de amor a las criaturas, sean las que sean, queda condenado como amor profano. Queda de manera muy especial el amor de hombre y mujer, que es siempre lascivo, lujuria, pecado; amor del que tanto hablan los tratadistas, los poetas, los dramaturgos, las novelas pastoriles y las de caballerías. Contra todos ellos arremete fray Pedro. Estamos en plena Contrarreforma.

"Que como si no bastaran los ruines siniestros en que nacemos y los que mamamos en la leche, y los que se nos pegan en la niñez con el regalo que en aquella edad se nos hace [nos parece oír a fray Luis de León]; y como si nuestra gastada naturaleza, que de suyo corre desapoderada al mal, tuviera necesidad de espuela y de incentivos para despertar el gusto del pecado, así la ceban con libros lascivos y profanos, adonde y en cuyas rocas se rompen los frágiles navíos de los mal avisados mozos, y las buenas costumbres (si algunas aprendieron de sus maestros) padecen naufragios y van a fondo y se pierden y malogran" 360. Entre los poetas, cita expresamente a Boscán y a Garcilaso; lo que no deja de ser una ingratitud, pecado entre pecados, pues él los leía, y los leía con gusto, y sin ellos no se explica su poesía, como no se explica la de fray Luis ni la de san Juan de la Cruz.

Del trato con las mujeres se ha de huir como del diablo, pues de ellas se sirve como "una añagaza, un despeñadero de almas" ${ }^{361 . ~ E l ~ a t a j o ~ m a ́ s ~ c o r t o ~}$ para vencer al hombre es la mujer. De aquí, de este "lodazal", nacen los demás pecados. Este es el vicio por el que vino el protestantismo; el que destruyó a Inglaterra, Alemania, Hungría, Flandes; el que despobló los monasterios, profanó los altares, y regó “el suelo con sangre de católicos" 362.

359. III, Prólogo del tercer estado de la Magdalena, 81-82.

360. I, Prólogo del autor a los lectores, 23-24. Cf. Bruno DAMIANI, El exordio de Malón de Chaide en LA CONVERSIÓN DE LA MAGDALENA, en Moralidad y didactismo en el Siglo de Oro (1492-1615), Editorial Orígenes, Madrid 1987, 113-124.

$361.1,2^{\mathrm{a}}, 12,234$.

362. I, $2^{\mathrm{a}}, 6,147$. 
El predicador que era Malón de Chaide se enardece, y su prosa se vuelve fuego. Una sola pregunta le haríamos: en las naciones que siguieron fieles a Roma, ¿no existía también este vicio? ¿Y en los papas del Renacimiento? Pero un predicador, un buen predicador, no atiende preguntas.

Matrimonio y trato con Dios no se avienen. "Moisén, como hablaba tan a menudo con Dios, se abstenía de su mujer" 363 . Los seglares quedan excluidos de la intimidad con Dios. Llamados a la santidad, pero condenados, de hecho, a vivir en sus arrabales.

Son muchas las desgracias del hombre, pero ninguna como la de ser hijo de mujer. Perdóneme el lector, pero tengo que darle alguna cita, por muy nauseabunda que sea. "La primera calamidad y miseria del hombre es que nace de mujer, de la más mudable sabandija de la tierra, de suerte, que allí se le pega la mudanza y poco asiento y la flaqueza en el bien. Mámalo en la leche, y sabe a la ruin pega del vaso donde se envasó" ${ }^{364}$. Por eso, cuando una mujer, por gracia especial de Dios, se adelanta en la virtud, está negando su condición de mujer. "Oh mujer, no mujer" ${ }^{365}$, apostrofa a la Magdalena. Y ahora deme gracias el lector porque le ahorro otras lindezas como estas sobre la mujer. La literatura eclesiástica, literatura de célibes, es una sentina sobre el tema. A pesar de lo cual, alguien ha ponderado la estima que Malón de Chaide profesaba a la mujer ${ }^{366}$.

\section{A SOLAS CON Dios SOLO}

Acción y contemplación se vieron en el cristianismo, desde muy pronto, como incompatibles y el fiel de la balanza se inclinó por la contemplación. Amar a Dios es contemplarle, tener siempre la mente fija en él. La contemplación se ama; la acción, a lo sumo, se tolera por necesidad de la caridad, siempre que el pensamineto siga unido a Dios. Así se leía el episodio evangé-

363. III, $4^{\mathrm{a}}, 60,149$.

364. III, $3^{\mathrm{a}}, 41,9$. Un pensamiento parecido en fray luis de León, $J, 14,1$.

365. El texto pertenece a un sermón de Orígenes que Malón de Chaide traduce y añade al final de su libro, III, 210.

366. Cf. Javier CLEMENTE, Pensamiento especulativo en La conversión de la de la Magdalena de Pedro Malón, en Revista Agustiniana 35 (1994) 648-652 y 660. El mismo autor le hace descubridor de los dinosaurios y de la extinción de especies animales, y se extasía ante su espíritu científico, sin percatarse de que los "monstruos gigantes, potentísimos guerreros" (III, $3^{a}, 44,37$ ) de que habla no son los dinosaurios, sino los gigantes que poblaron la tierra según dice la Biblia (Gn 6, 4; Bar 3, 26-28, texto que cita Malón de Chaide), libro del que procedían sus conocimientos científicos. Cf. $f b ., 656-658$ y 660 . 
lico de Marta y María y otros muchos pasajes de la Sagrada Escritura 367. El hombre nace para contemplar, dijeron los griegos, y su autoridad fue inapelable. Pero no es verdad que el hombre nazca para contemplar. Vivir es faenar con las cosas, y, cuando estas nos fallan, nos recogemos a pensar qué podemos hacer con ellas ${ }^{368}$. Esa es la función de la contemplación. Nuestra lectura, por otra parte, de los textos sagrados que se citaban en apoyo de las preferencias contemplativas, es muy distinta de la que hasta hace bien poco se hacía.

También Malón de Chaide recurre al episodio de Marta y María. El Señor llega a casa de las dos hermanas. "Asiéntase; y asiéntase a los pies María". Marta trajina por atender bien al Señor. María, "mano sobre mano", le escucha olvidada de todo lo exterior, absorta en su palabra. Marta se queja de su hermana; María ni se entera. "Quéjese Marta, venga cansado mi bien y mi amado; siquiera coma, siquiera no, que yo no cuido de eso. Amo, y en él está puesto mi cuidado. Murmure el fariseo, que yo a los pies de mi Amado me estaré segura.

¡Oh amor. más impaciente a las cosas del Amado que a las propias [...]. Mi Esposo vive en mi alma y yo vivo en él [...]. Vive mi Amado y se apacienta en mi alma" 369. "El Redentor respondió por ella, y al fin María fue la más amada, la de la contemplación, la de los favores y la regalada del Señor" 370.

Para amar a Dios es preciso renunciar al mundo y darse al recogimiento y la soledad, sin hacer caso de murmuraciones. "Veréis una pobrecilla mujer que tuvo alguna flaqueza, y si, vuelta de ella por la misericordia de Dios, trata de servirle, de confesarse a menudo, de ir al templo y de oír misa y recogerse, sale el otro fariseo y la otra mofadora murmurando: «sí, por cierto, mejor le estaría a fulana trabajar y estarse en su casa, que andar arrastrando confesonarios y royendo santos, hecha santera»" 371 .

Pero no basta con llevar una vida recogida. Hay que huir a la soledad; retirarse a algún monasterio o perderse en algún apartado desierto, desapareciendo para siempre de los hombres. Este es el camino de los perfectos. La Magdalena, decía una piadosa leyenda, que entonces era historia, después de la Ascensión del Señor se fue a Marsella con sus hermanos, Lázaro y Marta

367. Sobre la exposición que de ese pasaje hace san Agustín, así como de los de Lía y Raquel, Juan y Pedro, cf. José VEGA, La vocación agustiniana. El proyecto filosófico-monástico-sacerdotal de san Agustín, edic. cit., 433-532.

368. Cf. José VEGA, Acción y contemplación, en Estudio Agustiniano 31 (1996) 299-332.

369. III, $4^{\mathrm{a}}, 59,141-144$.

370. III, $3^{\mathrm{a}}, 46,65-66$.

371. III, $3^{\mathrm{a}}, 46,65$. 
(así se identificaban estos nombres del Evangelio). Al fin, cansada de todo, se adentró en un desierto, "adonde a sus solas pudiese gozar de la contemplación de su Amado. ¡Oh qué dulces ratos tenía entre aquellos riscos y por aquellas breñas! Arrebatábase en espíritu, y como si ya fuera vecina del cielo, y como si se desnudara del cuerpo mortal de que estaba vestida, así tan libremente, dejando la tierra, se subía donde vive su Amado. Allí miraba aquellas moradas celestiales de la soberana ciudad de Jerusalén; veíala llena de luz inmensa; sus calles y plazas que hervían de ciudadanos bienaventurados. Resonaba por aquellos ricos palacios una música que su dulzura desmaya, causada de la suavidad de las voces angélicas que alaban al gran Príncipe del mundo, sin cesar en un punto" 372. Como san Agustín, Malón de Chaide oía la música que nos llega de la casa de Dios 373. También la oía fray Luis ${ }^{374 . ~ " A ~ e s t a ~}$ celestial Jerusalén se subía la Magdalena con el pensamiento; y puesta en aquel desierto, arrebatada en espíritu, se entraba por aquellas moradas y palacios de la gloria, adonde veía lo que ni los ojos vieron, ni oyeron las orejas humanas, ni cupo jamás en terreno pensamiento lo que tiene Dios aparejado para los que viven allí sobre las estrellas" 375. "Y allí a veces se subía, / de la fuerza de amor arrebatada, / al cielo, adonde vía, / aquella alta morada / a do de amor quedaba desmayada" 376 ; pero el cuerpo la devolvía a la tierra, y sufría, acongojoda, en su destierro. "Allí seguía ella a su dulce Esposo, hablábale; acompañábale; estábase con él. ¡Oh dulce descanso y glorioso Paraíso el que tiene María en la soledad!" 377. "Pásase con raíces de hierbas, sin vestido, sin cama, sin regalo, sin compañía, sin trato ni conversación humana [...]. Al fin, habiendo pasado muchos años de soledad y penitencia, el celestial Esposo se la llevó" 378.

El religioso debe tener espíritu de ermitaño, vivir recogido en el monasterio, en trato asiduo con Dios. En soledad, aunque no en el desierto, vivía él, según dice. "Apartado del ruido del mundo y que ha dado consigo en la soledad [...]. Aunque no estoy en los campos, estoy en la soledad de la religión" ${ }^{779}$. Agradecido a los dones recibidos de Dios, canta sus misericordias en

372. III, $4^{\mathrm{a}}, 62,166 ;$ cf. I, $1^{\mathrm{a}}, 1,55-61$.

373. Cf. Comentarios a los salmos, $41,9$.

374. Cf. $P$, V, 16-20; P, XVI, 25-30; P, I, 81-85; N, 1, Pastor, 447.

375. III, $4^{\mathrm{a}}, 62,170$.

376. $\mathrm{Ib}, \mathrm{Ib} ., 174$.

377. Ib., Ib., 175.

378. III, $4^{\mathrm{a}}, 62,176-177$.

379. Exposición sobre el salmo 89 (88), que publica al final del tratado (en realidad, no lo comenta. Se limita a hacer una paráfrasis personal del primer versículo en octavas reales), III, 180. 
octavas reales. Cogiditos de la mano, como dos enamorados, se van él y su Esposo al campo, a gozar de su amor a solas. "Ya soy tuyo, mi Dios; ya tú eres mío [...]. / La primavera alegre es quien me viste, / y el alma de mil flores hermosea, / que en sólo arder y amarte a ti se emplea. / [...] Vámonos a la aldea y cogeremos / las rosas y azucenas que querremos. / [...] Saldremos a la huerta, a do la ardiente / siesta, en alguna fuente conversando, / la paseremos bajo algún aliso, / y no habrá para mí más paraíso. / [...] Entonces mano a mano nos iremos / cantando del amor que nos tenemos. / Allí me enseñarás, ¡oh dulce Esposo!; / allí me gozaré a solas contigo; / allí, en aquel silencio, alto reposo / tendré, mi Amado, en verte allí conmigo; / allí en fuego de amor, joh más hermoso / que el sol!, me abrasaré, y serás testigo / de que te amo así, que por ti solo / el día me es escuro, y negro Apolo" 380.

\section{El Dios de nUestros PadRes Platón y ARISTóteles}

\section{a) Amor de Dios a sí mismo}

Dios es "amante eterno de sí mismo" 381. Nada que objetar a esta afirmación; pero mis dudas sobre la autenticidad cristiana de este Dios comienzan cuando de él se dice que es incapaz de amar a nadie fuera de sí: "no amando cosa fuera de sí" ${ }^{382}$. Dios se contempla a sí mismo, y a sí mismo se ama, exclusivamente a sí mismo, porque, si amase algo fuera de sí, dejaría de ser Dios. Sería alguien imperfecto, menesteroso. Malón de Chaide insiste en esta idea, como veremos a continuación. Pero este Dios es aristotélico, no cristiano, y el amor con que se ama es puro egoísmo; un Dios encerrado en sí mismo, incapaz de salir fuera de sí.

\section{b) Amor natural de Dios al hombre en sí mismo}

El amor une al amante con el amado, le transforma en él, "hace unos al amante con el amado. Esto hace la voluntad; saliendo fuera de sí y pasando a lo que ama y, dejando su propio ser, toma el del amado" 383. Si amamos algo superior a nosotros, nos mejoramos; pero si amamos cosas de menos valor, nos degradamos, porque, al amarlas, "nos hacemos de más bajo ser, pues

380. Ib., íb., 184-186.

381. I, $1^{\mathrm{a}}, 1,55$.

382. $l b$., $i b$.

383. $t b ., i b ., 53-54$. 
cobramos el que tienen y perdemos el nuestro" 384 . El autor cita el conocido texto de san Agustín: "Si tierra amas, tierra eres; si cielo amas, cielo eres; y si a Dios amas, Dios eres" 385 .

Tal es la premisa que sustenta los minuciosos razonamientos sobre el amor de Dios, que son los de la tradición sobre el amor. Premisa a todas luces falsa porque no tiene en cuenta la realidad, tan peculiar y única, de la persona. Los ejemplos que los espirituales ponen para explicar cómo se transforma en Dios el alma que le ama, los del hierro o el madero que se transforman en fuego, lo prueban. La persona queda en ellos cosificada, asimilada a las cosas. El error de base está en dar por supuesto que el amor es identidad del amante con el amado, entrega, fusión, posesión, absorción, transformación, enajenación... Conceptos, evidentemente, inadecuados para expresar realidad tan personal, la más personal de todas; la que se da entre la mismidad de dos personas, manteniéndose las dos en su alteridad, mutuamente reconocida, afirmada y promovida; dejando cada una ser a la otra la que es y ayudándola a serlo en un proyecto común, en el que cada una es el proyecto de la otra, su estímulo y culminación de su vida ${ }^{386}$. De nada se ha escrito tanto, y de nada se sabe menos. Está todo por pensar.

Puesta la premisa, Malón de Chaide saca las consecuencias con lógica impecable. Si Dios nos amara, quedaría transformado en nosotros; perdería su propio ser y adquiriría el nuestro, sombra de ser y pecado. No puede amarnos en nosotros, sino solo en sí y por sí. "Dios nos ama en sí y por sí. Es muy gran verdad, porque no puede amarnos en nosotros, conforme a lo que hemos dicho, que el amado es fin del amante. Dios no puede tener alguna criatura por fin suyo, porque el fin es más noble, y como el que ama pasa en lo amado y cobra aquel nuevo ser, sería cobrar Dios vida y ser imperfecto, cosa que no puede ser. Ámanos, empero, por sí y en sí, adonde todos estamos y vivimos, y constitúyese por fin de su mismo amor, no amando cosa fuera de sí" ${ }^{387}$. Dios "ni puede vivir sino en sí, ni puede amar sino a sí; y siendo fin de todas las cosas y teniendo la perfección de todas ellas, no puede amar cosa fuera de sí. Por esto decimos que nos ama Dios en sí mismo y no en nosotros" 388 .

386. Cf. Julián MARÍAS, Antropología metafísica, Ediciones de la Revista de Occidente; Madrid 1973, 193-212; Id., La educación sentimental, Alianza Editorial, 1992, 273-283; José Antonio MARINA, El laberinto sentimental (Col. Argumentos 182), Editorial Anagrama, Barcelona 1996, 175-203; José ORTEGA Y GASSET, Estudios sobre el amor (Col. Austral 1338), Espasa-Calpe, Madrid 1966, $2^{\mathrm{a}}$; Id., Sobre el amor, Editorial Plenitud, Madrid 1963, $2^{\mathrm{a}}$. 387. I, $1^{\mathrm{a}}, 1,54-55$.

388. III, $4^{\mathrm{a}}, 48,135$. 
Para que Dios pueda amarnos "en sí” tenemos que estar en él. ¿Cómo nos tiene Dios “en sí"? Ahora vamos a Platón, a su teoría de las ideas ejemplares, herederas de los arquetipos celestes de las culturas antiguas. Todo lo sublunar es sombra de algo que tiene en el mundo supralunar, inteligible, su ser puro, acabado, su idea ejemplar. Los cristianos colocaron estas ideas en la mente de Dios, en su Verbo, por el que creó todas las cosas. Todo está en él. Todo tiene en él su idea ejemplar ${ }^{389}$. A esto hay que añadir las teorías sobre el símbolo del círculo o la rueda; sobre el centro, en el que habita la verdad en su esplendor, que irradia su luz sobre las circunferencias concéntricas en torno a ella; luz que se va apagando a medida que las circunferencias se alejan más del centro. También esta teoría fue cristianizada. Dios es el centro y hacia él miran, desde distintas circunferencias concéntricas, todas las criaturas, que sólo en él encuentran su reposo, porque cada criatura es llevada por su "peso" a su "lugar" natural. Teoría muy en boga en España en el Siglo de Oro (hay textos en los dos Luises, Cervantes...). Malón de Chaide la conoció y supo sacar partido de ella.

El centro del círculo, dice, es indivisible, fijo, inmutable. Del centro salen innumerables líneas divisibles, mudables, que se prolongan hasta tocar la circunferencia, "como lo vemos en los rayos de una rueda" ${ }^{390 . ~ L o s ~ r a y o s, ~ e n ~ e l ~}$ centro, se identifican con él, y en él se unifican todos. Cuanto más se apartan del centro, tanto más se alejan entre sí. La circunferencia voltea alrededor del centro, "como la rueda sobre el eje" ${ }^{391 .}$

"Dios es el centro universal de todas las cosas" ${ }^{392}$, simplícísimo, estable, indivisible ${ }^{393}$. Toda la rueda de las criaturas gira en torno a él. Todas ellas salen, como líneas, de su centro. En todas ellas está Dios, como está el punto en cualquier parte de la línea. Las criaturas, al apartarse de Dios, se hacen diferentes entre sí, como se hacen diferentes las líneas al alejarse del centro. Pero, si se vuelven a su centro, se hacen unas con él y entre sí. Lo que está en

389. Cf. San AGUSTÍN, Sermones, 117, 3.

390. III, $4^{\mathrm{a}}, 54,107$.

391. $f b$., $i b$.

392. fb., íb.

393. "Confieso que no he podido nunca asistir sin pena, sin temblor de humana compasión, al espectáculo ofrecido por estos cristianos medievales que viven hasta la raíz de su creencia religiosa, que chorrean fe en Dios, extenuándose en ver si logran pensar a su Dios como ente. Porque el Dios cristiano y el Dios de toda religión es lo contrario de un ente, por muy realissimum que se le quiera decir [...]. Con lo cual aconteció que no podían pensar de modo congruo el Ente, ni podían pensar idóneamente su Dios. Esta es la tragedia que se titula 'filosofía escolástica' (José ORTEGA Y GASSET, La idea de principio en Leibniz, Ediciones de la Revista de Occidente, Madrid 1967, 2a , II, 17-18). 
Dios, que es simple y sin accidentes, es sustancia simplicísima. "Luego es el mismo Dios" 394. Malón de Chaide lee "esta altísima teología en aquel grande y supremo teólogo san Juan" ${ }^{395}$. Hace falta tener un retículo mental muy especial para encontrar en san Juan círculos y ruedas, centros y circunferencias. Las elucubraciones del centro y la circunferencia más parecen las de un discípulo de Hermes Trismegisto que las de un cristiano.

Las criaturas, salidas de Dios, como las líneas del centro, no dejan de estar en él como estaban antes de la creación, siendo allí unas con él y entre sí. Porque todo lo creado y lo que Dios pueda crear "no es más que un retrato de las perfecciones que en sí tiene" ${ }^{396}$. El ángel, el hombre, el sol, la estrella y todas las demás criaturas son retratos de "las ideas o perfecciones" 397 que Dios tiene del ángel, del hombre, del sol, de la estrella... En las criaturas, las perfecciones son "finitas y de poco valor; en Dios son de oro, son el mismo Dios" ${ }^{398}$. En aquellas, son muchas y distintas; en Dios, son una sola y simplicísima. Vistas en el círculo, que es el mundo, son muchas; vistas en el centro, que es Dios, no son más que una, Dios.

Hoy todas estas disquisiciones nos suenan a zarandajas que oscurecen el Evangelio y la realidad de Dios.

\section{Amor natural de los ÁNGeles a Dios}

No es tema que aquí nos interese directamente, pero lo que de él dice puede servirnos de espejo para ver cómo tenemos que amar a Dios en él mismo y en cada uno de los que le aman. El amor lleva a los ángeles "enlazados y presos de un dulce y libre lazo para que tornen a la fuente y principio donde salieron" ${ }^{999}$. "Vanse aquellas mentes angélicas, atónitas, enajenadas de sí, libres sin libertad, presas sin prisión, como las mariposas a la llama. Allí se encienden y no se queman; arden y no se consumen; apúranse y no se gastan. [... Cada uno] se parece otra fragua de amor divino, y cada uno parece un Dios, digno de ser amado. Por eso, mirándose unos a otros, y viendo en cada uno aquel Dios, que tan dulcemente aman, no pueden dejar de amarse entre sí" ${ }^{400}$. Los ángeles son arrastrados libremente hacia Dios. Le aman por él

394. III, $4^{\mathrm{a}}, 54,110$.

395. $f b$., íb. Cita en su apoyo a Jn 1, 3-4 y 14, 6.

396. $f b$. íb., 111.

397. $l b$., $i b$.

398. $t b$., $i b$.

399. I, $1^{\mathrm{a}}, 1,55$.

400. $f b ., i b ., 55-57$. 
mismo, y, enajenados en él, se aman mutuamente viendo a Dios en ellos. Aman a Dios en él mismo y en ellos.

\section{AmOR NATURAL DEL HOMBRE A DIOS}

Todas las cosas tienden a su "centro" como a su "lugar" natural de reposo. Hay en ellas una "inclinación", "afinidad", "peso", "amor"... hacia su centro. Fuera de él están inquietas y pujan por alcanzarlo. "Si las quiere alguno violentar, rompen en efectos espantosos" 401. Nadie puede sostener los Alpes en el aire. El fuego tiende a su centro, a su esfera, y si lo encierran en un recinto, lo levanta todo por los aires, y lo destruye en busca de su lugar de reposo. Son los dos ejemplos que pone.

El centro del espíritu es Dios. Ninguna criatura puede detenerle en su marcha hacia él. "Si le cargase Dios con su poder todo el mundo junto, con todo ello daría al través y tiraría a su centro, que es Dios" ${ }^{402}$. Sólo el pecado es capaz de detener al alma y derribarla en el infierno. Tal es su poder. Fue capaz de derribar a criaturas mucho más poderosas, a los ángeles. Sólo un pecado se cargó multitud de ellos y entre ellos a Luzbel, el más aventajado serafín. Malón de Chaide insiste en estas ideas y las corrobora con algunos textos de san Agustín. El hombre tiene también"su "peso", su "amor", que le lleva hacia Dios. De él salió y a él tiende como a su "lugar" natural de reposo. "Hicístenos, Señor, para vos, para gozar de vos, para amaros a vos, y así nuestro corazón jamás halla descanso hasta que volvamos a vos" 403. "Todas las cosas tienen su peso y gravedad que las lleva tras sí; pero mi peso, dice Agustino, es mi amor; éste me lleva dondequiera que voy. De aquí es que en acertar a entablar bien la voluntad y amor consiste todo el juego de la vida; porque si este va errado, todo va errado; y si se acierta, todo se acierta" ${ }^{404}$.

Hay, pues, que despojarse de las criaturas, tirar lastre, para correr expeditos a nuestro centro. Hacia él, sólo hacia él.

Pero, según la Biblia, no es que nosotros amemos naturalmente a Dios, sino que él nos ha amado primero. "De su plenitud todos nosotros recibimos, ante todo un amor que responde a su amor" (Jn 1, 16). "Por esto existe el amor: no porque amáramos nosotros a Dios, sino porque él nos amó y envió a su Hijo para que expiase nuestros pecados" (1Jn 4, 10). Nuestro centro no

401. I, $2^{\mathrm{a}}, 4,120$.

402. $\{b$. $i b$.

403. I, $1^{\mathrm{a}}, 1,52$; san AGUSTÍN, Confesiones, I, 1,1 .

404. I, 1ª , 2, 62-63; cf. san AGUSTÍN, ib., XIII, 9, 10. 
está en un Dios separado de los hombres, sino en un Dios que vive en medio de ellos. "Así que la Palabra se hizo hombre, acampó entre nosotros" (Jn 1, 14). Nuestro centro no está en una región lejana, supralunar, sino aquí al lado, en los otros. Es ahí de donde soplan los vientos que fecundan la vida, y la hacen estallar madura de frutos. Ni sin ellos ni contra ellos, sino con ellos. Ser uno mismo, ser con los otros: haz y envés de una misma realidad, haz y envés de la persona. Los cristianos deberíamos saberlo mejor que ningún otro. El Padre de Jesucristo y Padre nuestro nos envía siempre a los otros; a dar libertad a los oprimidos y anunciar la Buena Noticia a los pobres; "a proclamar el año favorable del Señor" (Lc 4, 18-19). Lavar los pies de los otros es lo que hizo Jesucristo, "el hombre para los demás", según la acertada expresión de Karl Barth. “ Lavaos los pies unos a otros” $(\mathrm{Jn} 13,14)$ es lo que mandó hacer Ahí está el centro.

\section{AMOR POR GRACIA: DE Dios AL HOMBRE Y DEL HOMBRE A Dios}

Hay un amor natural de Dios, y hay un amor por gracia, sigue diciendo Malón de Chaide. Pero también ahora se le cruza la imagen del centro y la circunferencia, y hace una mixtura en la que todo resulta confuso y pesado.

Por gracia se unen las almas con Dios, su centro. "Confórmanse en todo con él y tienen una voluntad y un querer" ${ }^{405}$. En el centro, pusieron los filósofos la bondad; en la circunferencia, la hermosura ${ }^{406}$. Las almas contemplan la hermosura del Creador que resplandece en todas las cosas. Enamoradas de ella, las "lleva tras sí", $y$, al ver que es el rayo que nace de su bondad, "le aman y se hacen una cosa por amor con él y aun entre sí; porque como ven que todas las cosas tiran a su centro, amando a Dios, necesariamente han de amar lo que hallan en el mismo Dios" 407. "El mismo Dios es aquel cuya hermosura desean todas las criaturas, y en cuya posesión hallan su descanso. Lo que nace de la hermosura de Dios se dice amor [...]. Cuando viene a nosotros, enciende el apetito, y llámase deseo. Cuando, sacando al alma de sí la arrebata y lleva y une con Dios, se llama deleite; de suerte, que todo el círculo consta de amor en la hermosura de Dios, de deseo en nuestro apetito, deleite en la unión divina. Y cuando decimos amor, todas estas tres cosas encerramos en su nombre. Por esto se llama perfectísimo, porque por sí solo encierra los

405. III, $4^{\mathrm{a}}, 54,113$.

406. Cf. $f b ., i b ., 105$.

407. Ib., ib., 113-114. 
efectos de todas las virtudes y los frutos de ellas, y sin él, ninguna merece el nombre de virtud" 408. Cita en su apoyo el conocido texto de san Pablo en 1 Cor 13, 1-13; pero lo cita a su aire, y lo tergiversa llevándolo a su molino. San Pablo habla del amor a los demás, y él lo aplica al amor de Dios, sólo a Dios ${ }^{409}$.

Este amor de Dios por gracia pide Malón de Chaide para sí. "Tu amor te pido. Nolo tua sed te, dice san Agustín. No quiero, Señor, a tus cosas, sino a ti. Si tu amor me niegas, a ti te me niegas; y si tu amor me das, a ti te me das. Todas las otras cosas que tienes, comunes son a buenos y a malos; pero tu amor sólo es para los buenos, sólo para tus amigos. Con el amor lo tengo todo; sin el amor no tengo nada" 410 .

Quien ama a Dios por gracia es porque Dios le ha dado esa gracia; gracia que sólo da a los buenos, a sus amigos; a quienes ama, no en ellos ni por ellos mismos, que eso sería transformarse en ellos, tomar el ser de ellos y dejar el suyo, según el principio general antes formulado, sino en sí y por sí. El fin o el objeto del amor que Dios tiene a sus amigos sólo puede ser él mismo. Dios se ama a sí mismo en sí, y se ama a sí mismo al amar a los hombres en la idea ejemplar que de ellos tiene, y se ama a sí mismo en la gracia que da a sus amigos.

Pero todo este discurso del amor de Dios, tan prolijo según es usual en el autor, y tan meticulosamente articulado, se viene abajo con sólo abrir la Biblia, muy especialmente el Nuevo Testamento. Dios ama al hombre por el hombre mismo, en su realidad humana; al hombre de carne y hueso, no a una supuesta idea ejemplar que de él tiene, ni en la gracia que da a sus amigos. Dios ama todas las cosas. "Amas a todos lo seres y no aborreces nada de lo que has hecho; si hubieras odiado alguna cosa, no la habrías hecho" (Sab 11, 24). Ama a todos los hombres, no sólo a los buenos; también a los pecadores. "Juro que no quiero la muerte del malvado, sino que cambie de conducta y viva" (Ez 31, 11). "Cristo murió por todos" (2 Cor 5, 14). "Por la obediencia de uno solo todos serán constituidos justos" (Rom 5, 19). "Cristo murió por nosotros cuando éramos aún pecadores: así demuestra Dios el amor que nos tiene" (Rom 5, 8). ¿A qué seguir? El Credo lo resume bien: "por nosotros y por nuestra salvación bajó del cielo".

408. I, $1^{\mathrm{a}}, 3,64-65$.

409. Cf. $f b$., íb., 65-67.

410. fb. $i b ., 67-68$. 


\section{ENAMORACIÓN A LO DIVINO}

El amor del hombre a Dios tiene que ser exclusivo, limpio de todo afecto a las criaturas. A los textos ya dados hay que añadir estos otros.

"Amábate otro tiempo mi alma, dice la Magdalena; en ti tenía todo regalo y contento; a ti solo deseaba; tú eras la fuente de su vida; sin ti ni tenía bien, ni le quería; en ti gastaba sus pensamientos; contigo tenía sus ratos y pasaba sus conversaciones" 411. Pero pecó, y se apartó de su Amado. Ya "sólo me agradaban las criaturas y me deleitaban las cosas de la tierra" ${ }^{412}$. Se arrepiente, se aleja de las criaturas, también de sí misma, y vuelve a Dios. "Ya María se deja a sí; ya la Suma Bondad, que es el centro que dijimos de que salen todas las cosas, la mueve sin moverse; ya la Hermosura Eterna la tira a su centro, la une con él, la endiosa y la discuida de sí y de todo lo que es interés suyo" "413. María, junto al sepulcro vacío, toma a Jesús por el hortelano. "Toda ella está colgada de ti; toda está en ti; toda espera en ti; y toda desespera de sí: así te busca a ti, que nada busca fuera de ti, ni piensa en otro sino en ti, y aun por ventura por eso no te conoce a ti, porque no está en sí, antes por ti está fuera de sí" 414.

Se trata del amor de enamoración. María está enamorada de Jesús. En tal estado, el amante sólo puede pensar en su. amado; sólo a él puede amar. Cualquier otro pensamiento le resulta enojoso. Ahora bien, este es el amor de que hablan los libros que tratan de amores; un amor de fuertes connotaciones sexuales; un amor con frecuencia adúltero y siempre situado fuera del matrimonio, donde sólo se admitía el amor cristiano o caridad. Pues este lenguaje, como veremos inmediatamente, los espirituales lo trasladan a lo divino, y aplican al amor entre el alma y Dios lo que en los libros de amores, por ellos condenados, han leído.

"Y que muera el que ama está claro, porque su pensamiento, olvidado de sí mismo, se revuelve siempre en su amado; pues si no piensa de sí, luego no piensa en sí, y por esto el alma así aficionada no obra en sí, pues que la principal operación suya es el pensamiento; el que no obra en sí síguese que no está en sí, porque estas dos cosas son siempre iguales, el ser y el obrar [...]. Luego el alma del que ama no está en sí; y si no está en sí, claro está que no vive en sí, pues el que no vive, muerto es, y por esto decimos que el que ama

411. II, $3^{\mathrm{a}}, 36,207-208$.

412. Íb. $i ́ b ., 208$.

413. III, $4^{\mathrm{a}}, 49,141$.

414. Un Sermón que hace Origenes..., III, 206. 
está muerto en sí. Y de aquí nació aquel dicho: «que el alma más está donde ama, que donde anima» [...]. Vive en su amado. El amado vive en el amante y el amante en el amado: ama María a su Cristo, Cristo a su María. Juegan al trocado, y el uno se da al otro y el otro al uno, para que cada uno tenga al otro" 415. "Cristo, que es el Amante y el Amado, y el alma que es amada y amante, se truecan y se tienen el uno al otro. De qué suerte se dan el uno al otro, bien se ve, pues cada uno se olvida de sí [....Pero ¿cómo cada uno tiene al otro si no se tiene a sí?] Este es el milagro del amor, que perdiéndose a sí mismo cada uno, se tenga a sí y al otro [...]. El que ama tiene su vida en el amado [...]. Cuando yo os amo y pienso en vos, me hallo a mí mismo en vos; y en vos me cobro yo a mí, que me perdí por mi descuido, y vos hacéis otro tanto en mí" ${ }^{416}$. Como siempre, trae a colación textos bíblicos, que para él prueban lo que dice.

\section{LA LeNGUA DEL AMOR DE DiOS}

Al hablar del amor de Dios, le atribuimos a Dios actitudes y sentimientos humanos. Es un antropomorfismo. Es un lenguaje impropio, pero lo necesitamos para entendernos. Hablamos a nuestra manera. ¿Cómo podríamos hablar si no? "Estos afectos de amor impropiamente se dicen de Dios, porque ni puede vivir sino en sí, ni puede amar sino a sí, ni sentir esa muerte que decimos, pues es vida por esencia y la vida no puede morir" 417.

Tenemos que servirnos del lenguaje humano, pero ¿de cuál? Del lenguaje del amor, sin duda; pero ¡hay tantas clases de amor! ¿De cuál de ellas? Aquí está el problema. La tradición cristiana interpretó, desde muy pronto, el Cantar de los cantares, la más bella y más intensa y más embriagadora expresión de amor humano que jamás se haya escrito, en sentido alegórico; camino en el que ya se le habían adelantado los intérpretes judíos. Sus versos se leían a lo divino, como expresión de los amores de Dios e Israel, o de los amores de Dios y la Iglesia, o de Dios y el alma. Si Dios habló así, en términos de enamoración, no había que tener reparo en seguirle. Quedó así abierto el camino para poder usar las expresiones más audaces, de fuerte contenido erótico, incluso escabroso, en el amor místico. Y abierto el camino para apoderarse de las riquezas de los poetas paganos que hablaron de amores. Se podía

415. III, $4^{\mathrm{a}}, 58,134-135$.

416. fb., ib., 136.

417. III, $4^{\mathrm{a}}, 58,135$. 
leer también, por ejemplo, a Ovidio a lo divino. Con el tiempo, confluyó en esta corriente la gran riada de los místicos árabes. Quedó consagrado como vehículo del amor divino el lenguaje de la enamoración.

Conviene, sin embargo, hacer algunas puntualizaciones sobre el tema. El Cantar de los cantares celebra el amor de la pareja humana, varón y mujer, nada más; amor que se ve como "centella de fuego, llamarada divina" (Cant $8,6)$. Son canciones de boda y diálogos de novios en torno a su encuentro. $\mathrm{Su}$ lenguaje hierve y no conoce límites. Celebra, sin velos ni ocultaciones, el esplendor primaveral de los cuerpos y su gozo en la unión. Nada censurable, a no ser para espíritus pacatos, pretendidamente desencarnados. Quien admita la moralidad de este amor, tal era el caso de los judíos, puede usarlo, sin escrúpulos, para vehicular el amor divino. Tampoco los árabes tenían dificultad en ello. La amada era para ellos resplandor de Dios; era Dios quien se manifestaba en su belleza. El amor sexual era camino hacia Dios. Podía usarse como símbolo del amor místico 418 .

El problema se les presentaba a los cristianos. El amor, según ellos, era siempre lascivo, pecado. Mucho más un amor con claras tendencias sexuales. El amor y su lenguaje. Se citaba a san Pablo: "de lujuria [...], entre vosotros, ni hablar; es impropio de gente consagrada" (Ef 5, 3). El amor quedaba excluido del matrimonio. La sexualidad en él era trabajo; “débito" conyugal, decían, para la reproducción. Los esposos sólo podían amarse con amor espiritual, limpio de todo afecto humano; con caridad ${ }^{419}$. ¿ Cómo es posible que una realidad pecaminosa, el amor sexual, sirva de símbolo del amor divino? De él, decían los espirituales, que es lodazal inmundo, ciénaga que hace a los hombres brutos, y los empuerca. ¿Cómo usar vocabulario tan hediondo para explicar lo más puro y alejado de la materia? Por mucho que se purifique, y adelgace, san Juan de la Cruz fue un maestro consumado en estas artes, siempre le quedará el sabor de la carne pecadora, el aroma de los vinos de origen.

No se le escapó esta dificultad a Malón de Chaide. En la parte cuarta de su tratado, explica el estado del alma en gracia, "aquel regalo y dulzura de que goza el alma [...] que, renovada, se goza con su Amado, adonde experimenta otros nuevos gustos y otras ternezas más suaves que las que en el estado del pecado gustó [...]; el goce de los secretos que aquel mar inmenso de amor encierra en sí y comunica a sus santas esposas" 420 . Como "será menes-

418. Cf. Miguel ASÍN PALACIOS, El Islam cristianizado, Ediciones Hiperión, Madrid 1981, 245-247.

419. Cf. José VEGA, Sobre el "amor mutuo" de los cristianos, en Estudio Agustiniano 31 (1996) 108-112.

420. III, Prólogo del tercer estado de la Magdalena, 77-78. 
ter hablar del amor, quiero, antes de comenzar a hablar de sus grandezas, prevenir a V. M. y quitalle el escrúpulo que sé yo que su bondad y honestidad le podría traer" 421.

La palabra amor, razona con el Pseudo-Dionisio, tiene dos significados: uno mundano y otro divino. "Los profanos amadores del mundo tienen infamado este divino nombre; [y creen que sólo se puede usar] para tratar los amores profanos y sensuales, que mejor se llamarían brutales y furiosos" 422 . Conocemos este lenguaje. Ya los griegos vieron el amor como una "locura", una fuerza irracional que llega de fuera, y se apodera del hombre, y le esclaviza, y le hace hacer locuras; que "no es mucho amor el que se deja gobernar por razón. El amor no tiene reglas de crianza ni está atenido a leyes de palacio" 423. Los que "se alborotan", al oír esta palabra aplicada a Dios, sepan que se trata de un significado distinto del que tiene entre los profanos, y que "es menester en las cosas arduas explicar un término algo escuro por otro más claro" 424.

Al usarla en sentido divino, no hacemos usos nuevos. La Sagrada Escritura habla del amor de Dios, y en ella hay cantares amorosos, si bien no todos podían leerlos. "Los Cantares que hizo Salomón más honestos son que [las] Dianas; el Espíritu Santo los compuso, el más sabio de los hombres los escribió; entre esposo y esposa son las razones; todo lo que hay allí es casto, limpio, sano, divino y celestial y lleno de misterios, y con todo eso no daban licencia los hebreos a los mozos para que los leyesen, hasta que fueran de más madura edad" 425 .

En latín, sigue razonando con el Pseudo-Dionisio. hay dos palabras distintas para designar el amor: amor y dilectio. "aunque en castellano no se sufren bien por la pobreza de la lengua" ${ }^{26}$. Fray Pedro se ha olvidado del elogio que hizo de la lengua española en el prólogo de su obra, de su "gran riqueza y copia y mineros, que no se pueden acabar, de luces y flores y gala y rodeos en el decir" 427 . Algunos ínterpretes y tratadistas de las cosas divinas prefirieron amor a dilección. Otros, sin embargo, "les parecía que para con Dios no se había de usar el nombre de amor, como cosa ya aplicada a lo profano, sino el de dilección, que aunque quiere decir lo mismo, parece que dice el afecto de la voluntad con algo más moderación que el nombre de amor" ${ }^{428}$.

421. Ib., $i b ., 78$.

422. Ib., $i b ., 78-79$.

423. III, $4^{\mathrm{a}}, 59,142$.

424. III, Prólogo del tercer estado de la Magdalena, 79.

425. I, Prólogo, 27.

426. III, Prólogo del tercer estado de la Magdalena, 80.

427. I, Prólogo, 32.

428. III, Prólogo del tercer estado de la Magdalena, 80. 
Pero unos y otros dicen lo mismo con distintas palabras. "Los deílocos Padres, esto es, los que hablan de Dios, por lo mismo toman amor que dilección" ${ }^{229}$. Fray Pedro usa la palabra amor. "Yo no sé darle término en castellano a la dilección, que es latino" 430 . ¡Aviados estaríamos si borrásemos del castellano todos los términos latinos y los demás que provienen de otros idiomas!

Va a hablar de lo que el amor divino hizo en la Magdalena. "Y los profanos y torpes: procul hinc, procul este prophani; huyan lejos de nuestra conversación, ni se alleguen ni ensucien mis palabras con su torpe ingenio, que se correrá la muy enamorada Magdalena, y aun creo que se me destemplará la pluma si acaso los veo delante. No se atrevan a tratar con manos torpes y sacrílegas mi libro" 431. Para leer los escritos sobre los amores de Dios y el alma hay que salir del cuerpo y volar a la región divina; entrar en la sagrada calígine, donde todo suena santo y puro, embelesarse en Dios, endiosarse, "descubrir los admirables efectos y grandezas del gran Dios de amor" ${ }^{332}$.

El sermoncico ha entrado en calor, y la lógica se ha evaporado. Si hay que olvidarse de todo lo terreno y corporal, ¿no habría que olvidarse también del lenguaje de la enamoración, tan corporal y sexual? Porque no es que se use la palabra amor en dos sentidos muy distintos. Es que los espirituales siguen, paso a paso, los libros de amor profano sin que se les olvide ni un solo pormenor, desde los primeros escarceos hasta la consumación. Ahí están los poemas de san Juan de la Cruz. Tentado he estado, en más de una ocasión, a comentarlos con textos de Boscán y Garcilaso, de las Dianas y Celestinas, los Amadises y Floriseles y demás literatura, tan usada por los espirituales, aunque lo nieguen, y por ellos condenada tan sin piedad. ¿Por envidia de su éxito editorial? ¿Porque les arrebataba el monopolio de las almas? Quizá quedasen mejor aclarados que con las disquisiciones de filosofía escolástica a que el santo los sometió en sus comentarios en prosa ${ }^{433}$. Y ¿por qué no explicó nunca en prosa la

429. $f b ., i b ., 81$

430. Ib., ib., íb.

431. $\mathrm{fb}$, ib., íb.

432. Ib., ib., 82.

433. "Hay que tener el coraje de afirmar que san Juan nos desorienta e incluso nos desmerece como poeta cuando la necesidad de adoctrinar le obliga a concretar en sus tratadoscomentarios [...]. Leerle que -nada menos- «oh cauterio suave!, / ¡Oh regalada llaga!, / ¡Oh mano blanda, oh toque delicado!» tenga algo que ver con las tres Personas divinas, de modo que «el cauterio es el Espíritu Santo, la mano es el Padre, y el toque el Hijo» (Llama , 2, 1) parece dogmático, antipoético y, por supuesto, ingenuo. Pero él así lo vio, o dice que lo vio" (Ángel ALCALÁ, Poetas del amor y del silencio. A propósito de fray Luis de León y de san Juan de la Cruz, en Monte Carmelo 102 (1994) 45-46. Tal comentario, hay muchos otros del mismo estilo, emborrona lo que está claro, e inducee a los incautos a comulgar con ruedas de molino. 
unión amorosa del alma con Dios? Dos veces comentó por extenso el poema de la Noche. Nunca pasó de la tercera estrofa, teniendo el poema ocho. Explicó el camino hacia la unión, pero, al aproximarse a sus linderos, enmudeció ${ }^{434}$. ¿Sólo porque es inefable? Por esta razón, no tendría que haber escrito ni una sola línea, y todos tendríamos que enmudecer, pues toda experiencia humana, verdaderamente humana, es inefable. No es extraño que la comunión y otros ejercicios espirituales produjeran efectos turbulentos en gentes moldeadas por este lenguaje erótico, aunque divino. Lujuria espiritual la llamaron por experimentarse en el trato con las cosas espirituales, y aun encontraron razones para justificarla. Hablaré de ello en un próximo estudio sobre Eucaristía y convivencia según la Escuela Agustiniana Española del siglo XVI.

\section{AMOR A LAS CRIATURAS EN DIOS Y POR DIOS}

Dios es Bondad. De él parte un rayo que se derrama y penetra por las criaturas; por los ángeles, las almas racionales, la naturaleza "y últimamente en la materia, de que son hechas todas las cosas" ${ }^{435}$. Es su Hermosura. Neoplatonismo tenemos y también agustinismo.

"De aquí es que el que contempla y ama la hermosura en estas cuatro cosas, en las cuales se encierra todo lo criado, amando el resplandor de Dios y por él conocido en estas cosas, venga a conocer y amar al mismo Dios" ${ }^{436}$. "Nace de aquí que el ímpetu del que ama no se puede apagar, ni aun templar con la vista ni tacto de alguna cosa corpórea, porque no ama este a aquel cuerpo; mas sólo se admira y desea y se espanta del resplandor de la soberana luz que resplandece por el cuerpo, como la luz encerrada en vaso de cristal. Por esto los que aman, ni saben lo que buscan, ni entienden lo que quieren, ni conocen lo que desean. Ignoran a Dios, cuyo sabor escondido mezcló en sus obras un olor dulcísimo de sí mismo, con el cual olor nos despertamos cada día; porque este sentímosle, pero el sabor ignorámosle" ${ }^{437}$. Es lo que la "enamorada esposa" pide a su Esposo: que la arrebate tras el olor de sus perfumes, "al olor de su bálsamo y suavísimo ámbar" ${ }^{438}$.

434. Cf. Dámaso ALONSO, La poesía de san Juan de la Cruz (desde esta ladera), Aguilar, Madrid 1958, 116; en Obras completas, Editorial Gredos, Madrid 1973, II, 985-986. Sobre este mismo tema de La enamoración a lo divino y la lengua del amor de Dios he escrito en La soledad según fray Luis de León, en Revista Agustiniana XXXIX (1998) 391-400.

435. III, $4^{\mathrm{a}}, 55,119$.

436. Ib., íb., 120.

437. Ib., ib., ib.

438. fb., ib., ib. 


\section{Amor A los Amigos De Dios EN ÉL Y POR ÉL}

Dios es nuestro fin. Cualquier otro nos envilece. Luego no podemos amar al prójimo por él mismo, que eso sería hacerle fin de nuestras obras, sino por Dios y en Dios. Si Dios, como hemos visto, nos ama en él y por él, tanto naturalmente como por gracia, así debemos amar también nosotros al prójimo. Hay que amar a todos los hombres en la idea ejemplar que Dios tiene de ellos. donde todos somos uno con él. Hay que amar a los amigos de Dios en la gracia que Dios les da, y desde la gracia que nos da a nosotros. ¿Y a los demás? Malón de Chaide no trata el tema, pero podemos contestar de acuerdo con la tradición que el conocía bien: hay que amarlos por Dios para que lleguen a ser también sus amigos.

Por la gracia las almas se unen a Dios en amistad, y se conforman en todo con su voluntad, y se hacen "una cosa por amor con él y aun entre sí; porque como ven que todas las cosas tiran a su centro, amando a Dios, necesariamente han de amar lo que hallan en el mismo Dios [...]. Creo que como los santos, por el lazo de caridad y amor son unos entre sí y hacen un Cuerpo Místico, que dice san Pablo, así también viven de un espíritu y participan una misma vida [...], y se comunican entre sí sus méritos y bienes, y el uno ama en el otro la virtud que ve" ${ }^{439}$. Así se aman los que por gracia de Dios forman la Comunión de los Santos, el Cuerpo Místico de Cristo. Porque si son uno con Dios, por fuerza lo han de ser entre sí, según el conocido axioma: “quae sunt eadem uni tertio sunt eadem inter se, las cosas que son unas con una tercera, serán unas entre sí" ${ }^{440 .}$

El modelo de este amor es el de los ángeles y bienaventurados en la Jerusalén celestial. Enajenados en Dios, atraídos por él, le aman y se aman con un amor que no tendrá fin, "porque el amado Dios carece de fin [...]. De aquí desciende el amor a mezclarse entre los espíritus bienaventurados, y anda de pecho en pecho, tomando la posesión de todos ellos, y hace que se amen unos a otros, y no puedan dejar de amarse, porque, así como muchas piedras preciosas, puestas al rayo del sol, cada una representa otro sol, que deslumbra poco menos que el del cielo, así en cada serafín, y en los demás espíritus bienaventurados, heridos y rayados con aquella inmensa fuerza del amado eterno, Dios, se parece otra fragua de amor divino, y cada uno parece un Dios, digno de ser amado. Por esto, mirándose unos a otros, y viendo en

439. III, $4^{\mathrm{a}}, 54,113-114$.

440. fb., $i b ., 114$. 
cada uno aquel Dios, que tan dulcemente aman, no pueden dejar de amarse entre sí. ¡Oh ciudad enamorada, quién se viese en ti!" ${ }^{441}$.

Amar a las criaturas por ellas mismas, amar al prójimo con afecto humano es pecado. De aquí nace la lujuria. La Magdalena se alejó de Dios y se dio a las criaturas. "Ya el cielo me parecía feo y el sol sin hermosura; sólo me agradaban las criaturas y me deleitaban las cosas de la tierra. La hermosura me parecía que estaba en el cieno de mis torpezas y abominables pecados, y esta sola buscaba y dejábate a ti, belleza infinita" ${ }^{442}$.

Pero ¿es que no se puede amar a las criaturas en ellas y por ellas mismas? ¿No se puede amar al prójimo por él mismo? ¿Por qué no? ¿Dónde está prohibido? Dios nos ama por nosotros mismos; no puede estar más claro en la Biblia, y bien claro está en ella que debemos amarnos unos a otros por nosotros mismos, como Cristo nos amó, o como nos amamos a nosotros mismos, según otros textos. "Os doy un mandamiento nuevo: que os améis unos a otros; igual que yo os he amado, también vosotros amaos unos a otros" (Jn 13, 34). "Ama a tu prójimo como a ti mismo" (Mt 19, 19). Pero no siempre se entendieron así las cosas. "Hoy reconocen los teólogos que la espiritualidad «cristiana» nunca lo ha sido propiamente, sino que se ha evadido hacia el trascendentalismo y el espiritualismo. La fórmula «amar al prójimo por Dios», que es ya de por sí ambigua, ha sido objeto de una interpretación «espiritual» no ya ambigua, sino anticristiana, como se advierte en expresiones, tantas veces caídas de labios piadosos, como «si no fuera por Dios»..." 443.

Amar a Dios, amar al prójimo y amarse a sí mismo no son, cristianamente, tres amores que anden separados, cada uno por su lado. Quien se ama a sí mismo, no quien es egoísta o narcisista, amará a los demás porque sólo con ellos podrá ser él mismo. Y quien ama a los otros ama a Dios, lo sepa o no. El samaritano atendió al herido, y punto. Fueron los del discurso piadoso, el sacerdote y el levita, los que, al verle, se dieron media vuelta y le dejaron abandonado "por Dios" (Lc 10, 25-37) ${ }^{444}$. ¿Dios «contra» el mundo? Gabriel Marcel decía que estaba dispuesto a pasar por encima de la ortodoxia si era necesario.

441. I, $1^{\mathrm{a}}, 1,57$.

442. II, $3^{\mathrm{a}}, 36,209$.

443. Manuel OLASAGASTI, Estado de la cuestión de Dios, Espasa-Calpe, Madrid 1976, $50-51$.

444. Cf. José VEGA, sobre el "amor mutuo" de los cristianos, loc. cit., 79-117. 


\section{Algunos CONSEJos PARA BIEN VIVIR}

Reúno aquí algunas notas sueltas, muy en consonancia con lo que llevamos dicho. Al hombre no se le puede dejar solo. Necesita siempre un superior que le controle, muy especialmente la mujer. No hay que descuidar la compostura exterior, la modestia, el vestido, los andares, la mortificación en el hablar, los cilicios, ayunos y demás ceremonias. La sátira de Erasmo contra las "judaicas ceremonias" está ya lejos.

A algunos les parece que la Magdalena, "habiendo sido casada con un marido principal en Magdalo, ora por haberlo dejado, ora por ser muerto, comenzó a dejarse llevar de sus apetitos y dio en las libertades que suelen traer consigo las riquezas y la exención de superior, cuando este falta. Y así comenzó a gustar del billete y de la guitarrilla y del sarao y conversación, del paseo y fiestas y músicas, y de cosas semejantes, que, puesto que [aunque] no llegan a la persona, manchan al fin la fama y nombre y ponen nota en la vida" 445 . "No piense nadie que la compostura exterior, la modestia y reposo y las ceremonias cristianas, y andar un hombre o una mujer con un honesto vestido, los ojos recogidos, el paso reposado, las palabras contadas y pesadas y medidas, y que en su trato y meneo y ademanes, y en el revolver de los ojos y en todo lo demás, que mirar en esto y procurarlo hace poco al caso para conservar lo esencial de la virtud; porque antes es de tanto peso y tan importante, que tengo casi por imposible que la bondad interior se conserve sin estas muestras exteriores [...]. Son como el seto o valladar que guarda la viña" ${ }^{446}$. "Anda Juan con una piel de camello, más áspero que cilicio, los miembros desnudos, quemados del sol, el rostro tostado, que apenas tiene talle de hombre, que este es el traje de que más se agrada Dios [...]. «El vestido del cuerpo y la risa de los dientes y el movimiento del cuèrpo, dice el Sabio, que descubren quién es cada uno» (Ecclo 19, 30). Vuestro traje, vuestra risa demasiada y descompuesta, y vuestro meneo y pasos lascivos y muelles os apregonan y dicen vuestra disoluta vida" ${ }^{447}$.

\section{RUPTURA CON LA FAMILIA}

Hay que huir del mundo, extirpar todo afecto a las criaturas, romper todo lazo que nos ate a los demás. La familia no es una excepción. También en ella

445. I, $2^{\mathrm{a}}, 7,152$.

446. fb., ib., 153.

447. I, $2^{\mathrm{a}}, 10,194$. 
hay que erradicar los afectos humanos. Hay que dejarlo todo por Dios, quemarlo en holocausto. La vida del hombre es una continua batalla (Job 7,1). "Lo que se conquista es el cielo, y quien la gana es el que pelea como valiente. Pues el soldado no peleará bien con faldas largas, por esto mandaba el Señor dejar la hacienda, la honra, los hijos, la mujer, el padre, madre, hermanos, y aun a nosotros mismos; porque ¿qué otra cosa son las que habemos nombrado, sino faldas que nos vamos pisando, y que nos arrastran y embarazan para la batalla?" 448 . El soldado pelea mal con ropa larga. El faldicorto está más suelto y pelea mejor. "Así, ni más ni menos, los ricos y poderosos, como van cargados de faldas de haciendas, de estados de honra y ambición y de muchos contentos, cuando quieren arremeter a la batalla, písanse la falda larga de la hacienda y hácelos dar de narices en la avaricia; y el otro tropieza en la falda de los hijos y cae de ojos en la tiranía, por dejar a sus hijos en estado y grandeza. Y así de todo lo demás. Pero el pobre tiene cercenadas las faldas, sin hacienda, sin amigos, sin ambición y sin estado; corre, pelea, vuela y pasa por las cosas de la vida, triunfando del mundo y de cuantos hay en él" 449 .

El elogio de la pobreza le ha salido redondo. Para hacerlo no tuvo que devanarse los sesos. La tradición conventual era un minero a este respecto. No deja de ser curioso que los elogios de la pobreza los hicieran quienes no la padecían, como elogiaban el campo y la vida de aldea quienes vivían en la ciudad. Siempre que los leo, me viene al recuerdo el comentario que hace el socarrón moro Benengeli sobre las riquezas de los monasterios cuando a don Quijote "se le soltaron hasta dos docenas de puntos de una media, que quedó hecha celosía [...]. Ha de tener mucho de Dios el que viniere a contentar con ser pobre, si no es de aquel modo de pobreza de quien dice uno de sus mayores santos: «tened todas las cosas como si no las tuviésedes»; y a esto llaman pobreza de espíritu" ${ }^{450}$.

448. II, $3^{\mathrm{a}}, 16,25$.

449. Ib., ib., 25-26.

450. Miguel de CERVANTES SAAVEDRA, El ingenioso hidalgo don Quijote de la Mancha (Clásicos Castellanos 19), Espasa-Calpe, Madrid 1967, parte 2a , 44, 133-135. Francisco RODRÍGUEZ MARÍN pone en nota este texto de san Pablo : "et qui utuntur hoc mundo tanquam non utantur, los que disfrutan del mundo, como si no disfrutasen" $(1 \mathrm{Cor} 7,31)$, que nada tiene que ver con el texto que cita Cervantes. La cita está tomada de 2 Cor 6, 10: "tanquam nihil habentes et omnia possidentes, como quienes nada tienen, aunque todo lo poseemos" 


\section{LA SEDUCCIÓN DE LAS RIQUEZAS}

Dejemos tan altas cumbres y echemos pie a tierra. El texto de Cervantes que acabo de citar nos ayuda a ello. Hay que huir del mundo. Algunos hacían profesión de ello. ¿Huían? Hay que desembarazarse de las riquezas, de los estados de honra y ambición. La pobreza es el camino real para ir al cielo. Así será, pero la realidad desmentía con frecuencia tan solemnes proclamas Hay un pasaje en La conversión de la Magdalena, una de sus páginas más animadas, que es como una ventana por la que podemos contemplar un momento de la vida conventual del siglo XVI.

"Llega el otro, desuellacaras, homicida, robador de los pobres, con mil pecados mortales, que el menor dellos escandaliza el aire; dice que se quiere confesar y que viene de priesa, que no se puede detener; es menester que se despidan los que ha un mes que no hallan vez para confesarse, porque llega el señor don Fulano" 451 . Hay un ir y venir de pajes por los confesonarios en busca del Padre Maestro Fulano; menudean los recados y las embajadas, "el ir en persona el Prior o el Guardián, que se desembarace y lo deje todo, aunque esté a media confesión, que otro día la acabará, y si no que no importa, que está esperando el señor don Fulano. Veréis al confesor echar gente menuda abajo, levantarse y salir del confesonario más hinchado que algún privado necio, que apenas cabe por la Iglesia, y el claustro se le hace angosto.

En tanto, vuestro penitente se está paseando, renegando del confesor y de su tardanza. Al fin sale el Padre Maestro a acompañar a su penitente;-llévale a la celda, porque son pecados de cámara los que trae. Hinca la una rodilla, como ballestero; persígnase a media vuelta, que ni sabréis si hace cruz o garabato, y comienza a dar de dedo y a desgarrar pecados, que hace temblar las paredes de la celda con ellos; y si el confesor se los afea, sale con mil bachillerías, y dice que un hombre de sus prendas no ha de vivir como vive el fraile, y parécele que todo le está bien. Al fin, sálese tan seco y tan sin jugo como entró, y el desventurado muy contento, como si Dios tuviese cuenta con que desciende de los godos" 452 .

Como contraste, he aquí la confesión de un pobre: "veréis llegar al otro pobrecillo temblando, y antes que ose pedir por el confesor, se derrueca allá tras la pila de bautizar, y allí llora sus pecados y los gime. Después, cuando ya le quieren admitir, llega temblando y tragando saliva, y añúdansele las palabras en la garganta, que del miedo no las puede sacar del pecho, y no osa

451. II, $3^{\mathrm{a}}, 32,166-167$.

452. Ib., íb., 167-168. 
levantar los ojos a mirar al confesor. Pues ya, si lo que confiesa le dicen que es pecado mortal, veréisle perdido el color y temblar, que piensa que allí donde está se lo ha de tragar la tierra, y llora y pide perdón con miedo y humildad" 453 .

Esta página, tan mordaz y llena de vida, es una acertada actualización de la párabola del fariseo y el publicano (Lc 18, 9, 14). Azorín aludió muy fugazmente a ella: "Malón de Chaide, prosa recamada, coloreada, vocablos y frases del mundo; joyas, «espejos de cristal, pomas de ámbar gris, pañizuelos labrados», un gran señor que va a confesarse, el paje que pone «la almohada de terciopelo para que el señor no se lastime»" 454.

\section{LOS AZOTES DEL P. PRIOR}

Una sola frase es suficiente para introducirnos en el mundo inhóspito de la convivencia conventual. Mundo de mando y obediencia, de culpas y castigos, de espías (celadores), cárcel y disciplinas. Cristo "andaba siempre aparejado a disciplina, como cuando un religioso comete una culpa, que le manda el prelado aparejarse a disciplina, desnudas las espaldas do las recibe" 455 .

El beato Orozco habla, lo hemos visto, de castigos corporales; de que los superiores pegaban a los súbditos, o sea, les daban disciplinas; del resquemor de éstos por los azotes recibidos, y les pide que no se venguen. Fray Luis de León dice que a los religiosos hay que aguijarlos con el látigo. Malón de Chaide nos informa de que los superiores disciplinaban a los súbditos en las espaldas desnudas. También santa Teresa habla de estas disciplinas en los mismos términos, y completa la información. A veces, no las daba el superior, sino que mandaba a un súbdito que las diera. Advierte a la superiora, aviso muy teresiano, que no mande que disciplinen "las mozas a las antiguas" 456.

De las Constituciones de las Órdenes religiosas y muy especialmente de los Estatutos de los conventos se podría sacar una antología de estas prácticas de azotes y cárceles, impuestas para mantenimiento de la santa observancia, es decir, del orden divino, y gloria de Dios; impuestas, se decía, por caridad. ¿Dónde quedaba el consejo de san Pablo: "como buenos hermanos, sed

453. Ib., íb., 168. $\mathrm{m}$.

454. Los clásicos redivivos. Los clásicos futuros (Col. Austral 551), Espasa-Calpe, Madrid $1973,4^{\mathrm{a}}, 47$.

455. II, $3^{\mathrm{a}}, 35,195$.

456. Constituciones, 12,1 y $14,1$. 
cariñosos unos con otros, rivalizando en la estima mutua?" (Rom 12, 10). Pero no juzguemos aquellas vidas con nuestros criterios. Tratemos, por el contrario, de entenderlas. El horror que todo esto nos produce hoy indica la distancia estelar que media entre ellos y nosotros en la comprensión del hombre, de Dios, de Jesucristo... y, en consecuencia, de la vida religiosa.

Y es que los religiosos son, como todos, hijos de la sociedad en la que nacen y viven, por mucho que entonces dijeran y profesaran huir del mundo. Del mundo no se huye nunca, es imposible. Se puede uno aislar de los hombres, pero el mundo lo lleva dentro. Vaya donde vaya, es parte constitutiva suya.

Los azotes eran entonces, lo habían sido antes, y lo seguirían siendo después, un procedimiento expeditivo en la enseñanza y el escarmiento. Azotó Dios a su Hijo, se decía, en sustitución de los hombres pecadores. "Los azotes que hicieron nuestras paces con el Padre cayeron sobre él" 457. Pues, a pesar de esas paces, el Padre siguió azotando a sus hijos sin piedad. Dice Isaías $(1,5-7)$ en versión parafraseada de Malón de Chaide: "grandes han sido vuestros pecados y muy grande mi sufrimiento y espera que, en disimularlos, he tenido. Castigado he muchas veces, cansado estoy de andar a los palos con vosotros, y siempre malos; ya no sé qué me haga; ¿dónde os azotaré, pues no hay parte sana en vosotros? ¿Y tras eso, siempre malos, siempre pecadores, siempre pecando de nuevo, hechos pedazos, y no cansados, y no enmendados? Tantas veces me habéis provocado a saña con vuestros pecados, que os he desollado de pies a cabeza, de suerte que ya no hay parte que no esté bañada en sangre, y siempre tijeretas [tercos]" ${ }^{458}$. Hablar así de Dios es métáfora "de un padre que tiene un hijo travieso, y con deseo de enmendarle le castiga, azótale, y no hay género de castigo que no lo ejecute en él; pero es tan malo el muchacho que no siente ya los azotes. Viéndole el padre siempre peor, dice: «¿qué haré con este bellaco? Ya no sé dónde castigarle; hele abierto a azotes, tráigole siempre vendado y quebrado los cascos, ya con la pierna desconcertada, ya quebrado el brazo, y él siempre peor»" 459 .

Azotaba el padre a los hijos y todos contentos. "Cuando el padre está enojado con el hijuelo, azótale y los azotes son los que hacen las amistades, y parece que el muchacho queda contento, con que ya ha pagado a su padre el enojo que le había hecho; y han hecho las paces" ${ }^{660}$. Azotaba la madre a los

457. II, $3^{\mathrm{a}}, 35,196$; cf. Is 53,5 .

458. I, $2^{\mathrm{a}}, 11,225$.

459. $f b$., íb., 226.

460. II, $3^{\mathrm{a}}, 35,195-196$. 
hijos. Fray Luis de León nos ha descrito la escena inolvidable de una mujer "brava", áspera de condición. "Cuando comía, reñía, y cuando venía la noche, reñía también [...]. Siempre se oía el grito y la voz áspera, y la palabra afrentosa y el deshonrar sin freno y ya sonaba el azote y ya volaba el chapín" ${ }^{461}$. Azotaba el esposo a la esposa, y por contenta se podía dar si no pasaba a más. Azotaban los dómines a los discípulos. Azotaban los curas párrocos a los jóvenes y niños. Azotaban los misioneros a los indios, "que, en faltándoles el azote, como niños son perdidos", según dice un eclesiástico de la época ${ }^{462}$. Se azotaba a los esclavos y a los criados. Se azotaba a los delincuentes paseándolos por las "acostumbradas", por las calles señaladas para ello, a hora fija, con gran regocijo de la chiquillería. Azotaba el Santo Oficio, experto en tormentos de la más variada índole. Azotaban o mandaban azotar los priores, los maestros de novicios y profesos y todos los constituidos en dignidad y gobierno. Azotes, azotes, azotes en todo tiempo y lugar.

\section{UN TEXTO HUMANÍSTICO FUERA DE CONTEXTO}

Al crear Dios al hombre como pequeño mundo o microcosmos, compuesto de materia y espíritu, le dijo: "ni te damos cierto asiento, ni propio rostro, ni don particular, porque la silla que conforme a tu albedrío, y el rostro y los dones que tú deseares y quisieres escoger, esos tengas. Todas las demás criaturas tienen limitadas leyes y naturalezas: a ti ningunas te estrechan. Por tu albedrío, en cuya mano te he puesto, has de hacerte ley; púsete en medio del mundo para que de allí mirases mejor lo que hay en él. Ni te hicimos celestial ni eterno, mortal ni inmortal; tú has de ser como árbitro y nuevo entallador de ti mismo. Podrás degenerar en las cosas inferiores, que son los brutos, y podrás transformarte en las superiores y divinas, según te pareciere" ${ }^{663}$. "Oh suma liberalidad del Padre celestial!, comenta el autor de este texto. ¡Oh admirable felicidad del hombre, a quien fue dado tener lo que desea, ser lo que quisiere!" 464.

Estas palabras nos deslumbran por lo luminosas que son. Pero no son, es evidente, de Malón de Chaide. Hablan desde otro mundo; desde el hombre y

461. La perfecta casada, en Obras completas castellanas, edic. cit., 15, 322.

462. Cit. por Henry MECHOULAN, El honor de Dios, prólogo de Julio Caro Baroja, Editorial Argos Vergara, Barcelona 1981, 43.

463. I, $1^{\mathrm{a}}, 3,103$.

464. $f b$., ib., $i b$. 
su libertad. Son del humanista Pico della Mirandola ${ }^{465}$, aunque Malón de Chaide no nos lo diga (el pasaje que cita es bastante más de lo que he dado). Los hombres del Renacimiento escribían sobre falsilla, imitando modelos. Con frecuencia, copiaban sin citar la fuente. Es lo que hace Malón de Chaide. No siempre fuente y texto coincidían. A veces, como aquí, cada uno va por su parte. Las palabras de Pico son una incrustación extraña en La conversión de la Magdalena; una nota discordante en la música que en ella suena. Al leerlas, dan ganas de saltar de gozo. Son un hito en la historia del humanismo; un hito, ¡ay!, pronto enterrado.

Pico pide que el hombre se afirme como hombre, que se ame. Malón de Chaide y los espirituales que se niegue a sí mismo, y se desprecie, y se odie; que se vacíe de sí mismo y de toda otra criatura; que se apoye sólo en Dios y se llene de él. Pico exalta la dignidad del hombre, del hombre en cuanto tal, de su misma condición humana, sin añadidos de ninguna clase. Malón de Chaide afirma la miseria del hombre, polvo y pecado, nada; del hombre, que de suyo es indigno. Sólo la gracia de Dios, transformándole en hijo suyo, le hace digno. Dios, dice Pico, dejó al hombre sin acabar para que se realice a su albedrío. Él verá qué figura elige, y qué rostro y cualidades se da, y qué asiento se prepara. Es libre: esta es su dignidad. Todo está en sus manos: elegir su propio ser, lo que va a ser, y serlo; ser él mismo; ser lo que libremente se vaya haciendo. No tiene naturaleza, no tiene ser, ni leyes externas que le digan cómo tiene que ser y qué caminos seguir. Su camino lo hará él al andar. Como en el cantar de Antonio Machado, "caminante, son tus huellas / el camino, y nada más; / caminante, no hay camino, / se hace camino al andar" ${ }^{466 . ~ C a d a ~}$ uno es ley de sí mismo, escultor de su propia vida, plastes et fictor, dice Pico. Es pura plastilina; está en medio del mundo, entre la materia y él espíritu. Escoja hacerse animal o dios, mortal o inmortal.

Ser su propia ley, ser él mismo. ¿Qué tiene que ver esta visión cristiana del hombre, según Pico es Dios el que le hizo así, con la que en estas páginas se nos ha dado? Aquí todo está atado y bien atado. El hombre tiene naturaleza. Se le ha dado un ser; se le ha puesto un centro hacia el que gravita por necesidad; se le han impuesto leyes, muchas leyes que le dicen todo lo que tiene que hacer, y, si algo no está claro, hay maestros que se lo dirán, a los que

465. Oratio Joannis Pici Mirandulae, concordiae comitis, en Joannis PICI MIRANDULlAE Opera omnia, Venetiis 1498, sin paginación. Cf. la traduc. española, Oración sobre la dignidad del hombre, Madrid 1984, 105.

466. Proverbios y cantares XXIX, en Campos de Castilla, en Poesía y prosa, edic. crítica de Oreste Macrí, Espasa-Calpe / Fundación Antonio Machado, Madrid 1989, II, 575. 
tiene que obedecer so pena de condenación eterna. Esta es su única libertad: seguir el camino de la salvación o el de la condenación, los dos perfectamente trazados de antemano. ¿Libre para seguir uno $\mathrm{u}$ otro? Dejemos intacto el tema, tan erizado, de la predestinación, profusa y confusamente tratado por Malón de Chaide en los términos más burdos ${ }^{467}$, porque llegaríamos a encontrarnos con la libertad hecha trizas.

En términos actuales, podemos decir que Pico afirma la autonomía moral del hombre, una autonomía, repito, que tiene a Dios por fundamento, mientras que Malón de Chaide y los espirituales afirman una y otra vez la heteronomía. Son dos mundos opuestos, dos comprensiones distintas de Dios y del hombre, dos morales, dos espiritualidades, dos maneras de vivir el Evangelio, dos paradigmas, en suma.

Nos puede ayudar a perfilar estos dos mundos la distinción que Sáinz Rodríguez estableció entre dos clases de humanistas. El humanismo nació como estudio de las humanidades, de las lenguas clásicas, latín y griego. Pero entre los que lo cultivaron hay notables diferencias. Uno es el humanismo de la Contrarrreforma y otro el de los humanistas laicos del Renacimiento. Son dos visiones espiriutales distintas: "Yo creo que en el humanismo coinciden una serie de concepciones de la virtud procedentes de los moralistas clásicos, con las doctrinas del cristianismo; pero en cuanto a las prácticas religiosas en la vida ordinaria, hay una línea que yo delimitaría así: en el humanismo existe la moderación, en el cristianismo la mortificación. Jamás, creo yo, encontraremos un texto humanístico en donde se preconice la mortificación, el sufrimiento como necesidad de la vida espiritual" ${ }^{468}$.

Hubo y hay muchas clases de humanismo. Hubo humanistas entregados a la depuración de los textos clásicos. Hubo estudiosos del latín y el griego que expurgaban los textos ad usum Delphinis, y prohibían las obras de humanistas como Erasmo y Luis Vives. Hubo humanistas que escribían libros atiborrados de notas eruditas, sin interés ninguno, como el licenciado que acompañó a don Quijote camino de la cueva de Montesinos, que tenía escrito un Suplemento a Virgilio Polidoro, donde averiguaba las cosas que éste se dejó en el tintero, entre otras "quién fue el primero que tuvo catarro en el mundo" 469 . Hubo humanistas prontos a la embestida, enemigos del hombre, fanáticos. Hubo humanistas con una nueva sensibilidad estética, formada en

467. Cf., por ejemplo, II, $3^{\text {a }}, 15,7-17$ y 16, 18-32.

468. Pedro SÁINZ RODRÍGUREZ, en AA. VV., Homenaje a Luis Vives, Fundación Universitaria Española, Madrid 1977, 16.

469. Cf. Miguel de CERVANTES SAAVEDRA, El ingenioso Hidalgo don Quijote de la Mancha (Clásicos Castellanos 16), Espasa-Calpe, Madrid 1957, parte 2a , c. 22, vol. VI, 78. 
diálogo con los textos ejemplares del pasado. Hubo humanistas que buscaban la verdad desde su momento histórico, abiertos, tolerantes, críticos frente a lo transmitido, innovadores, amigos y defensores del hombre. Entre ellos, Pico della Mirandola, Erasmo, Vives, Nebrija, Tomás Moro... La enumeración no es cerrada ni excluyente. Algunos de ellos pertenecieron a varias de estas clases. La distinción que aquí nos interesa es la de humanistas defensores del hombre en cuanto tal, de su libertad y dignidad, y humanistas partidarios de la mortificación y demás ceremonias, de la negación del hombre y afirmación de la gracia de Dios, que es la que le da su dignidad. Las virtudes del hombre son valiosas por sí mismas, dicen los primeros. Las virtudes del hombre sin la gracia de Dios son vicios, dicen los segundos; no hay valores humanos. El Concilio Vaticano II está con los primeros.

"En España, el periodo inmediatamente postridentino, llamado tantas veces «humanista», niega los valores centrales del humanismo para desembocar en el barroco" 470 . Por eso, uno de los apartados del libro al que pertenece esta afirmación se titula: "Los dos Luises o la derrota del humanismo" ${ }^{771 .}$

\section{CONCLUSIÓN}

\section{HACIA UNA NUEVA CULTURA DE LA CONVIVENCIA}

A lo largo de estas páginas he ido señalando las notables diferencias que nos separan de los autores aquí estudiados y de la tradición por ellos representada. Tantas que estamos en otro mundo. Son otros nuestros afanes y otro nuestro modo de encarar la convivencia.

Tres textos de diferentes autores confirmarán lo que acabo de decir. Uno es de Laín Entralgo, otro del papa Juan Pablo II y el tercero de Julián Marías.

"Por carácter y por oficio yo tiendo a no ser "anti". Al "o esto o lo otro", yo prefiero el "esto y lo otro, sólo que de otro modo". La vida, por añadidura, me ha enseñado a mirar con mucha cautela todas las actitudes "anti", porque bajo todas ellas suelen latir, indiscerniblemente mezclados, el miedo, la agresividad y el fanatismo; el miedo, sí, aunque el hombre "anti" sea capaz de arriesgar su vida atacando aquello a que él se opone. Pero-admirando, desde

470. Julio RODRÍGUEZ PUÉRTOLAS (Coord. ), Historia social de la literatura española, Editorial Castalia, Madrid 1978, 254.

471. Id., Ib., 255. 
luego, todo lo que en el famoso librillo de Tomás de-Kempis es cristianamente valioso, y reconociendo, por supuesto, todo el bien espiritual que la lectura de sus páginas haya producido a lo largo de los siglos- debo confesar que frente a ciertas sentencias de la Imitación de Cristo, tan directamente influidas por la mentalidad de la época en que fueron escritas, invenciblemente me siento un poco anti-Kempis. «Cuantas veces estuve entre los hombres, volví menos hombre» 472 . Aun cuando tantos hombres de veras cargantes haya en el mundo, aun cuando tantas cosas en los hombres sean en verdad cargantes, ¿puede un verdadero cristiano decir eso en serio, olvidando que el hombre, por deshombrecido que en su vida esté, es por esencia imagen y semejanza de Dios, y que Dios, para redimirnos, hombre y no piedra del yermo quiso hacerse? “¿De qué te sirve saber definir la compunción si no la sientes?”. Por lo menos me servirá, pienso yo, para saber con cierta precisión lo que en sí misma es ella, qué es en su realidad propia algo que yo debiera sentir y no siento; lo cual, si la definición es buena, acaso me ayude a sentir de veras la compunción. “¿Qué se te da a ti de las distinciones de los lógicos?”. En el refectorio de su convento, un tomista chapado y contrachapado oyó leer esta rústica, antiintelectual pregunta; y sin poder contenerse, replicó con voz tonante: “¡Pues a mí, sí!”. No tan tomista como él y con voz más queda, lo mismo digo yo" 473 .

"Sí, dice Juan Pablo II, el marido no busque únicamente sus intereses, sino también los de su mujer, y esta los de su marido; los padres busquen los intereses de sus hijos, y estos a su vez busquen los intereses de sus padres. La familia es la única comunidad en la que todo hombre "es amado por sí mismo", por lo que es y no por lo que tiene. La norma fundamental de la comunidad conyugal no es la de la propia utilidad y del propio placer. El otro no es querido por la utilidad o placer que puede procurar; es querido en sí mismo y por sí mismo. La norma fundamental es, pues, la norma personalística; toda persona (la persona del marido, de la mujer, de los hijos, de los padres) es afirmada en su dignidad en cuanto tal, es querida por sí misma" ${ }^{474 .}$

Hay que amar a los otros en ellos, por ellos y para ellos mismos. Hay que amarse a sí mismo por sí y para sí mismo, porque Dios nos ama en nosotros,

472. "Dice uno: «siempre que fui a los hombres, volví menor hombre». Lo cual experimentamos por cierto cuando mucho hablamos" (Imitación de Cristo, trad. al castellano de fray Luis de Granada, Aguilar, Madrid 1989, primer tratado, XX, 63).

473. Pedro LAÍN ENTRALGO, La sociedad actual ante el téologo, en Teatro del mundo (Col. Austral 1672), Espasa-Calpe, Madrid 1986, 317-318.

474. Homilia durante la misa para las familias cristianas en la plaza de Lima, en Mensaje de Juan Pablo II a España, BAC popular, Madrid 1982, 77. 
por nosotros y para nosotros mismos. Insiste en ello en la Veritatis Splendor: "En este precpto [del amor al prójimo] se expresa precisamente la singular dignidad de la persona humana, la cual es la «única criatura en la tierra a la que Dios ha amado por ella misma»" 475 , como dice el Concilio. El texto del Concilio al que se refiere el Papa dice: "El Señor, cuando ruega al Padre que todos sean uno, como nosotros también somos uno (Jn 17, 21-22), abriendo perspectivas cerradas a la razón humana, sugiere una cierta semejanza entre la unión de las personas divinas y la unión de los hijos de Dios en la verdad y en la caridad. Esta semejanza demuestra que el hombre, única criatura terrestre a la que Dios ha amado por ella misma, no puede encontrarse plenamente a sí mismo si no es en el don sincero de sí mismo a los demás" ${ }^{476}$.

Leamos el Kempis, pero con criterio. Su lectura nos ayudará a entender muchas cosas de las que han pasado y alguna zona de nosotros mismos. No seamos esclavos de su letra. Sepamos distanciarnos de ella y de su contenido; encarar la convivencia, los muchísimos valores que hay en ella, con un nuevo espíritu; vivirla humana y cristianamente, identificados con el proyecto de Jesucristo; tomar posesión intelectual de ella. Tomar posesión de esta terra incógnita no va a ser fácil.

Amemos a las personas en ellas y por ellas mismas; a las personas concretas, en su individualidad peculiarísima, aunque otra cosa hayan dicho los venerables maestros que conformaron nuestra juventud. Nada mejor para saber qué grado de relación tenemos con alguien que comprobar el efecto que su muerte nos produce.

"Probablemente, dice Julián Marías, la manera más segura y eficaz de determinar si nuestras relaciones humanas son simplemente eso o llegan a ser estrictamente personales es ver qué significa para ellas la muerte. Las primeras, al morir la otra persona, quedan conclusas, canceladas, persisten en forma de recuerdo que carece de actualidad. En el otro caso, persiste la viveza de la relación, el desgarrón, la herida siempre sentida, en suma, la privación. Todo ello, por supuesto, en muy diferentes grados, que van de lo soportable y capaz de cicatrizar a lo devastador y destructor de la configuración de la vida" 477.

¡Ojalá llegue pronto el día en que, en nuestras comunidades, la muerte de un religioso deje heridos a los que se quedan, porque echan en falta al compañero que se les ha ido! El grado de intensidad que tenga ese echar en falta será indicador del grado de relación que con él se tenía. Hoy por hoy, somos

475. Veritatis Splendor, 13.

476. GS, 24.

477. Mapa del mundo personal, edic. cit., 90. 
incapaces de entrever, ni siquiera entrever, las consecuencias que en la sociedad y en la familia traerá esta nueva visón de la convivencia, y el vuelco que tendrá que dar aún la vida religiosa, a pesar de los cambios ya realizados.

JosÉ VEGA, OSA

Estudio Teológico Agustiniano

Valladolid 